\title{
A Model of Regional Allocation of Funds for the Ownership of Capital Assets of the Health Sector
}

\author{
Iman Shaker Ardakani ${ }^{1}$ \\ i.shaker@ardakan.ac.ir \\ Mohammad Shaker Ardakani² \\ Im.shaker@ardakan.ac.ir \\ Abolfazl Shahmohammadi Mehrjardi ${ }^{3}$ |shahmohamadi@stu.yazd.ac.ir
}

\begin{abstract}
The health sector and the funds allocated to it, due to its impact on the strengthening of the human capital through productivity, play an important role in the economic growth and human development of countries. If these credits are not allocated optimally, especially in the form of capital asset acquisition, it will make the health sector unable to provide optimal health care services. In this regard, the purpose of the present article is to provide a model for allocating the funds for the acquisition of capital assets of the health sector in Khorasan Razavi to the cities of this province. To this end, a multi-criteria decision-making method has been used on the basis of satisfaction and statistics and information related to credits and indicators of the health sector of Khorasan Razavi province with emphasis on deprived and less developed areas. The findings of this study indicate the highest optimal share for the cities of Mashhad, Binalood, and Zaveh and the lowest optimal share for the city of Gonabad from the total credits related to the acquisition of capital assets of the health sector of Khorasan Razavi.
\end{abstract}

Keywords: Healthcare, Allocation, Credit, Capital Asset, Multi-Criteria Decision Making.

JEL Classification: H81, C61, H51.

1. Assistant Professor, Department of Economics, Faculty of Humanities \& Social Sciencies, Ardakan University, Ardakan, Iran, (Corresponding Author).

2. Assistant Professor, Department of Management, Faculty of Humanities \& Social Sciencies, Ardakan University, Ardakan, Iran.

3. Ph.D. Student, Department of Economics, Faculty of Economics, Management \& Accounting, Yazd University, Yazd, Iran. 


\section{ار ائه الخَوى تخصيص منطقهاى اعتبار ات تملك

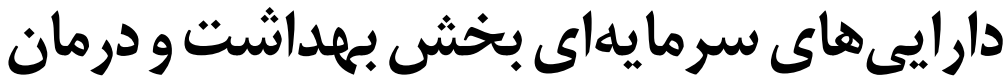

i.shaker@ardakan.ac.ir

m.shaker@ardakan.ac.ir

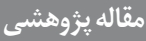

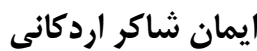

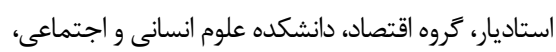
دانشكاه اردكان، اردكان، ايران (نويسنده مسئول).

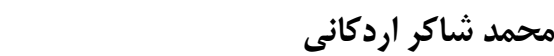

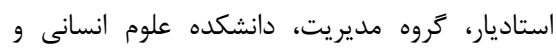
اجتماعي، دانشكاه اردكان، اردكان، ايران. shahmohamadi@stu.yazd.ac.ir

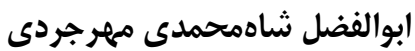

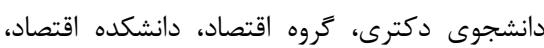
مديريت و حسابدارى، دانشكاه يزد، يزد، ايران.

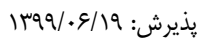

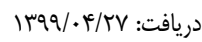
جكيده: بخش سلامت و اعتبارات تخصيصى به آن به دليل تقويت سرمايه انسانى از مسير

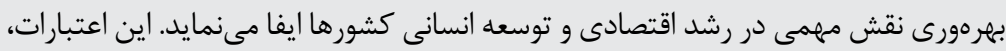

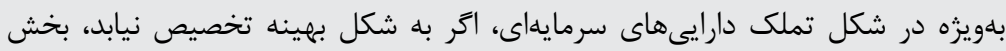

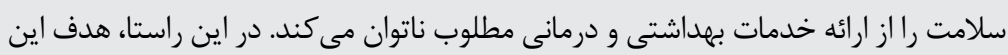

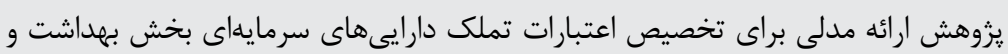

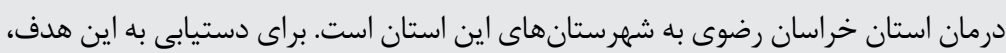

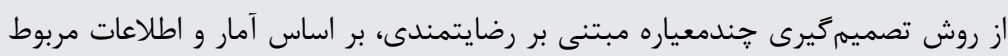

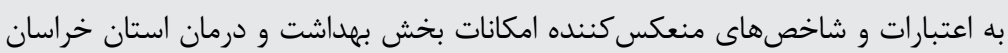

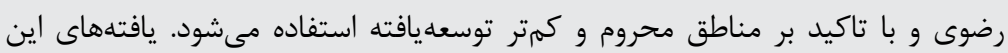

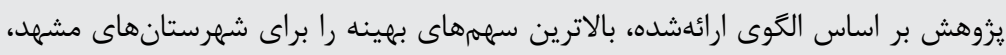

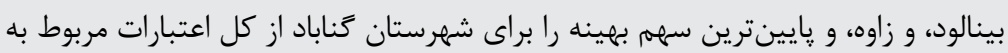

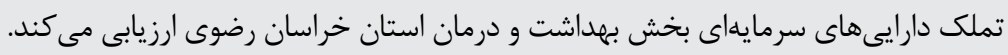

كليدوازهها: بهداشتودرمان، تخصيص،اعتبارات، دارايى سرمايهاى، تصميمَيرى جندمعياره طبقدبندى H81, C61, H51:JEL. 
بخش سلامت به عنوان يكى از اركان اساسى در توسعه انسانى، همواره بخش اعظمى از منابع و بودجه دولتها را به خود اختصاص ميدهد. اين در حالى است كه اين بخش با تقويت سرمايه انسانى از مسير بهرهورى و انباشت سرمايه انسانى نقش مهمى در رشد و توسعه اقتصادى ايفا مى كند

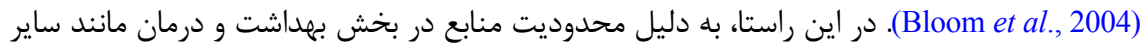
بخشها از يكسو، و نامحدود بودن نيازهاى جامعه از سوى ديكر، مسئله تخصيص بهينه منابع در اين بخش مطرح مىشود. تخصيص بهينه منابع مهممترين ابزار اجراى راهبردها و برنامههاى بلندمدت در درئر

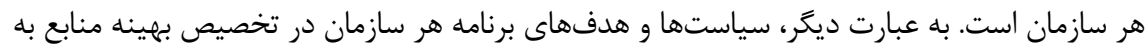

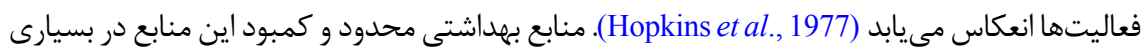

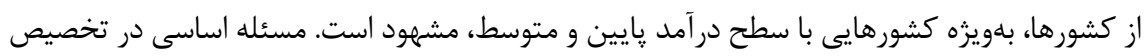
منابع بهداشتى اين است كه اگر اين تخصيص رضايتبخش نباشد، جگَّنه بايد تغييرهايى ايجاد كرد و

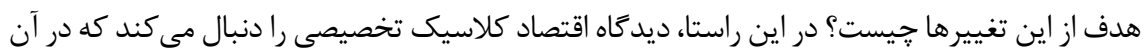
بيشترين رفاه اجتماعى فراهم شود. با وجود اين، هدف تخصيص منابع بهداشتى، بيشينه كردن سلامت دين

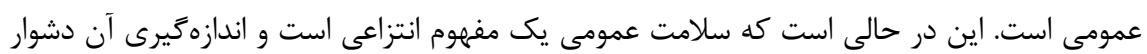

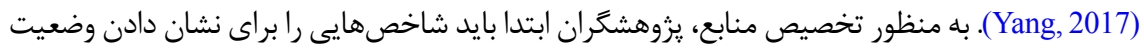

منابع تهيه كنند كه بيشتر مبتنى بر سطح جمعيت است (Birch et al., 1993).

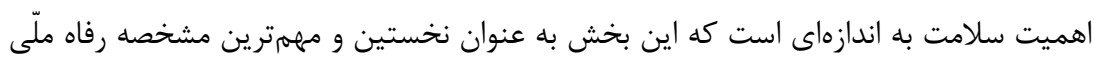

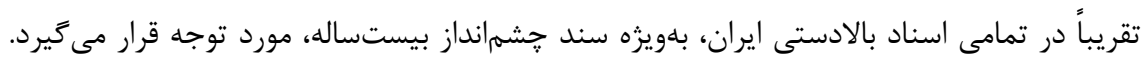

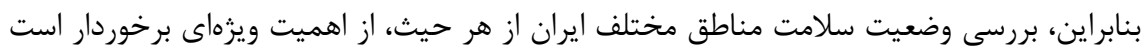
و كام مهمى براى تخصيص بهينه منابع سلامت ميان مناطق مختلف كشور به منظور تحقق اهداف

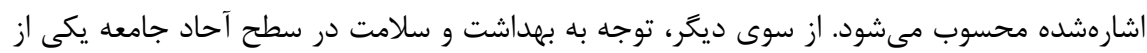
اهداف اصلى برنامههاى جمهورى اسلامى است. در اثبات اين كَته مىتوان به مواردى مانند قانون اساسى جمهورى اسلامى ايران اشاره كرد كه ضمن محورى برشمردن سلامت كامل و جامع انسان، بهداشت و درمان را از جمله نيازهاى اساسى مىشناسد و دولت را مكلف مى كند كه تمامى منابع، امكانات، و ظرفيتهاى خود را براى تامين، حفظ، و ارتقاى سطح سلامت افراد كشور بسيج كند. از اينرو، يكى از ابعاد تجلىبخش مديريت خدمات بهداشتى و درمانى كشور، ارائه خدمات بهداشتى و و و 
درمانى به اقشار مختلف جامعه است (آذر و رجبزاده، (1) (1). بديهى است در راستاى تحقق اين امر

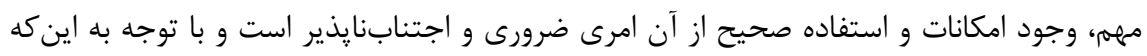
حفظ و تامين سلامتى مردم از اولويتهاى توسعهاى هر كشور بلهشمار مىرود، دستاندر كاران بخش سلامت همواره در تلاش هستند كه با بهرهيرى از منابع در دسترس خود، بهترين و كيفىترين هرمين مراقبتها و خدمات بهداشتى ـ درمانى را به جامعه ارائه كنند. اما در مورد روش و مدل مورد استفاده در تخصيص منابع بخش بهداشت و درمان، به دمانه

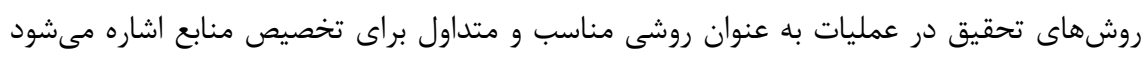

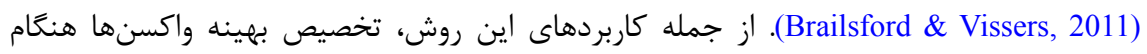
شيوع سل و مالارياست (Parker, 1983). اين در حالى است كه در طول دهdهاى كذشته، روشهاى نهاى

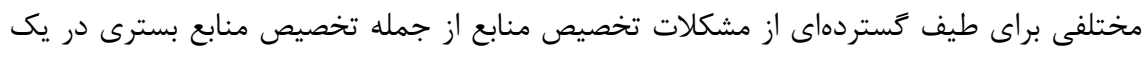
محيط بيمارستانى (Vissers, 1998)، تجزيلوتحليل سياستهاى مديريت سيسته موجودى خون

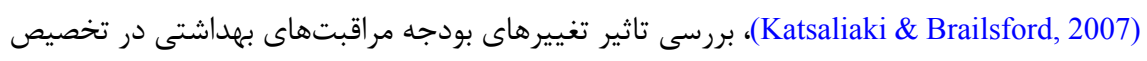

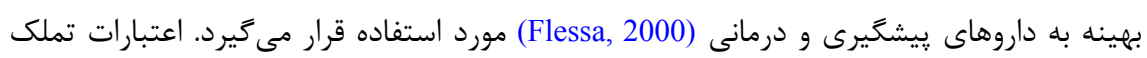
دارايى سرمايه بخش بهداشت و درمان از جمله منابع مالى است كه با هدف ارائه خدمات بيشتر دهر،

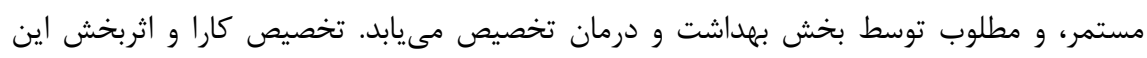

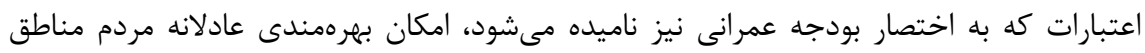

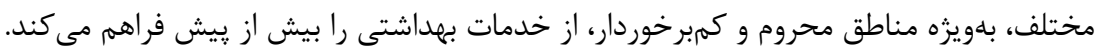

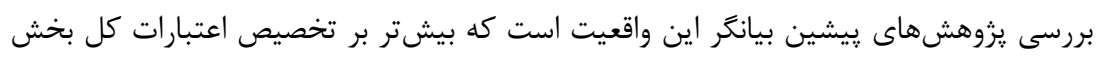

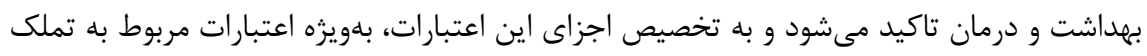

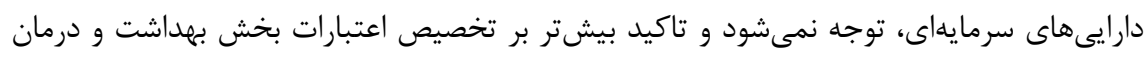

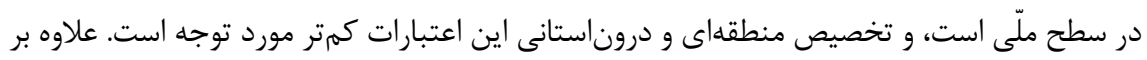

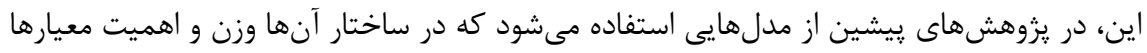

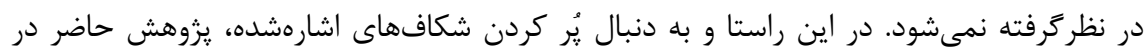

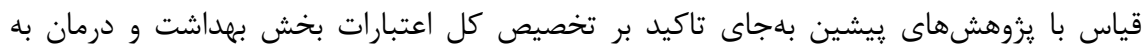

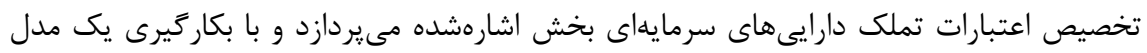

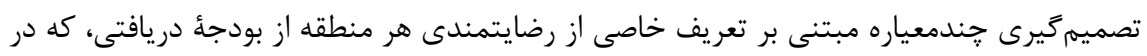

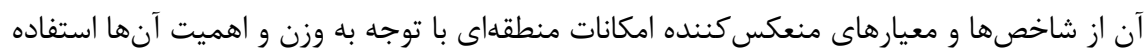


مىشود، سهم و ميزان اعتبار يرداختى به هر شهرستان را دقيق مشخص مى كند. اين در حالى است

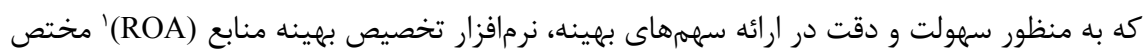
حل مدل معرفى شده نيز طراحى شده است.

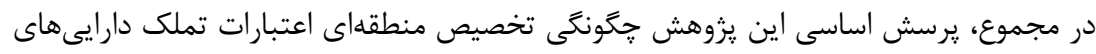

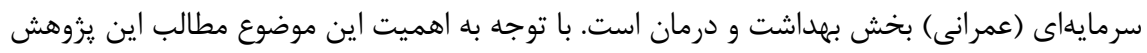

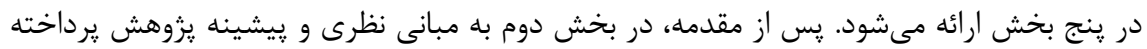

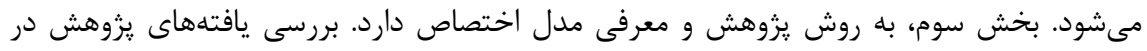

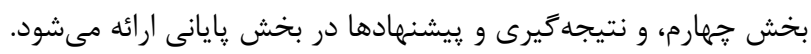

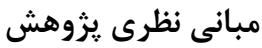

انسان از ديرباز با كميابى منابع در دسترس و تلاش براى تخصيص اين منابع به خواستههاى نامحدودش روبهرو بوده است. با توسعه جوامع بشرى و گسترش مباحث مالى مسئله تخصيص بهيع دئن

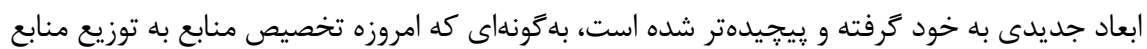
ميان گَروههاى رقيب از افراد، نهادها، سازمانها، و برنامهها اشاره دارد. در اين وضعيت، زمانى كه تقاضاى

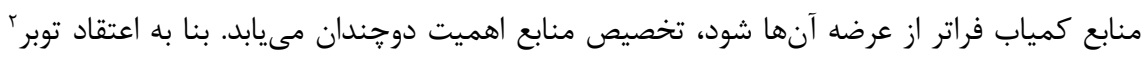

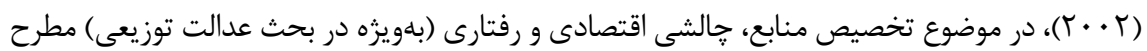

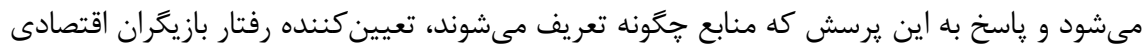

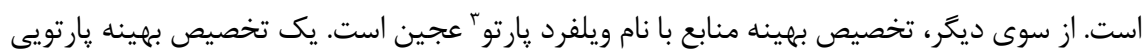
هنگًامى قابل ناممكن باشد. علاوه بر اين، در صورتى كه در يك تخصيص اوليه از منابع ميان مجموعهاى از افراد، تغيير در تخصيص باعث بهبود شرايط فردى بدون تغيير در شرايط فردى ديگر شود، ارتقاى (بهبود) پارتو

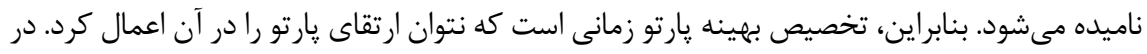

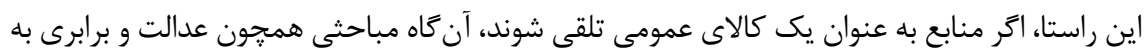
عنوان مفاهيمى برخاسته از اقتصاد رفاه اولويت مى يابد و برجسته مىشود. ولى اتى اتر منابع به عنوان كالاى

1. Resources Optimal Allocation

2. Tauber

3. Vilfredo Pareto (1848-1923) 
خصوصى تعريف شده باشد، آن گاه تخصيص منابع در ابعاد مختلف و مباحث رقابتى و بيشينهسازى منفعت بيشتر مورد ملاحظه قرار مى گيرد. از سوى ديگر، از ديدگاه اقتصادى تخصيص منابع بلهطور

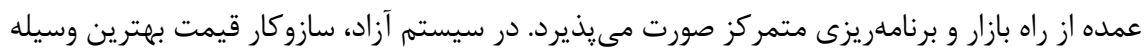

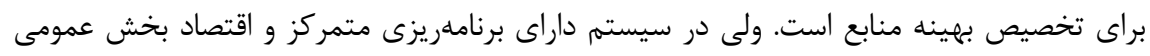

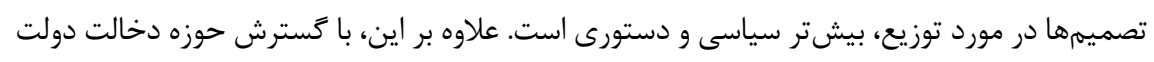

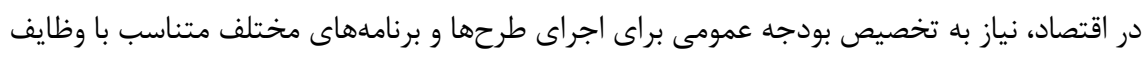

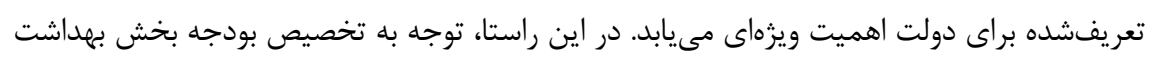

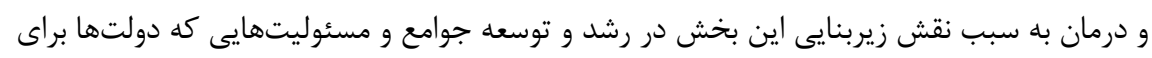

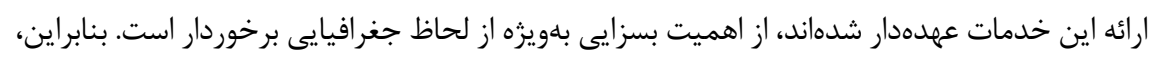

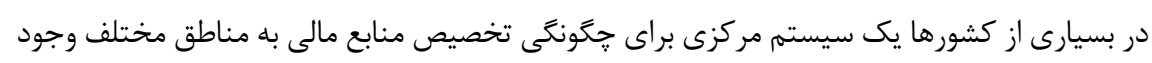

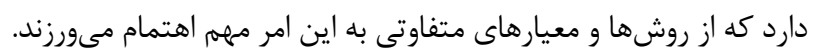

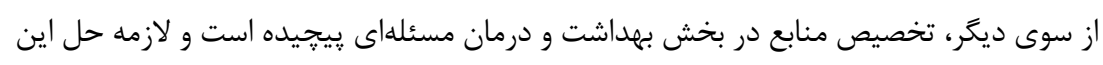

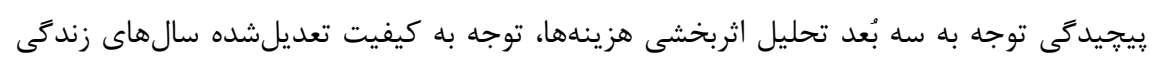

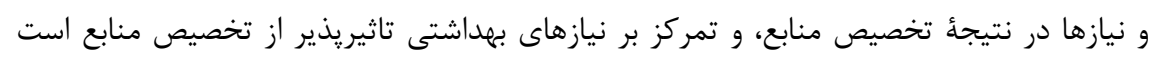

.(Gugushvili, 2007)

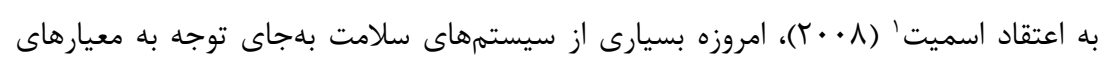

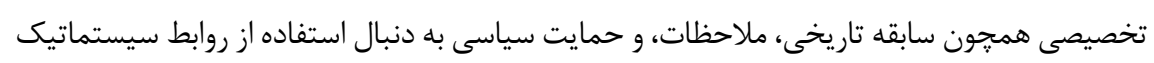

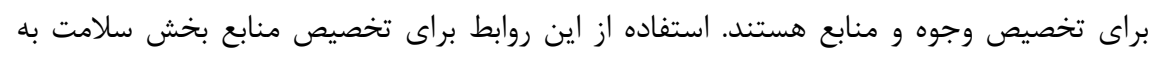

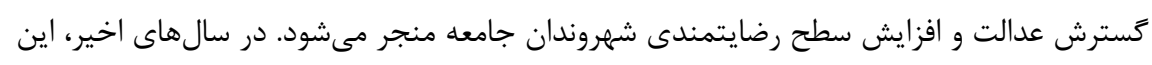

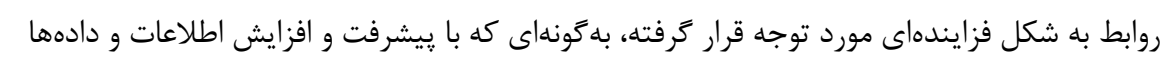

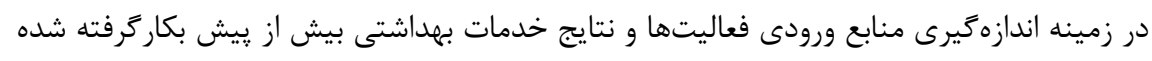

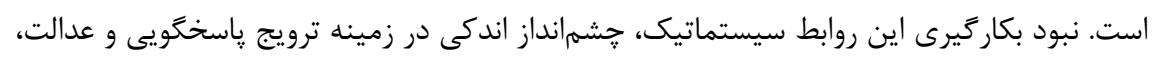
يیشاروى نظام سلامت يك كشور قرار مى دهد. در فرايند تدوين و تخصيص منابع، مدلسازى يكى ابزار

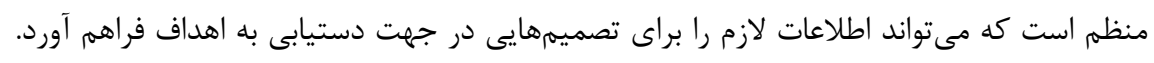

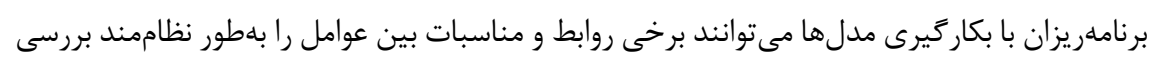

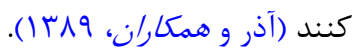


بنابر اين، با توجه به مباحث مطرحشده در اين يزوهش سعى مىشود مدل و رابطهاى سيستماتيك براى تخصيص اعتبارات تملك دارايىهاى سرمايهاى بخش بهداشت و درمان استان خراسان رضوى برى

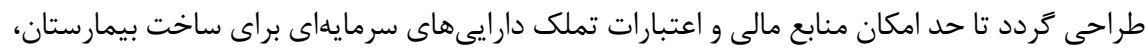

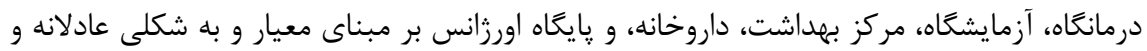
در جهت حمايت از مناطق كمتر توسعهيافته اختصاص يابد.

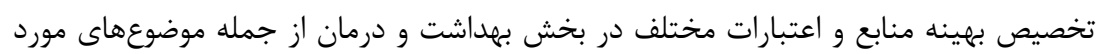

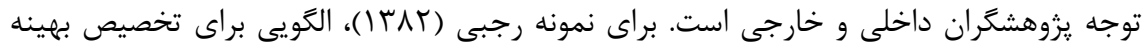

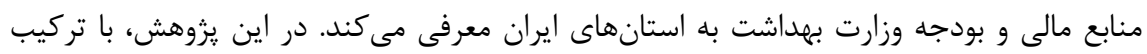

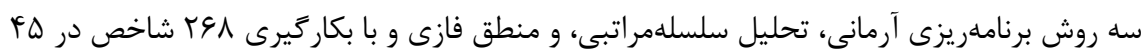

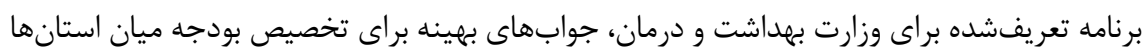

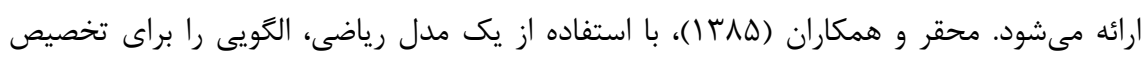

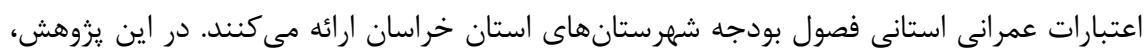

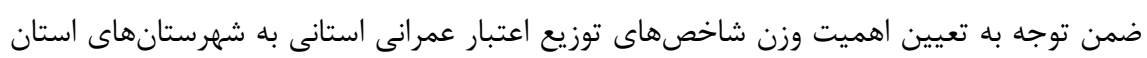
خراسان، فاصله وضع موجود هر شهرستان تا وضع مطلوب تعيين مىشود كه همان اهداف برنامه

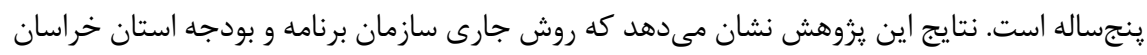

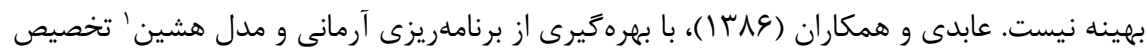

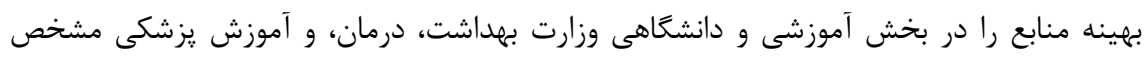

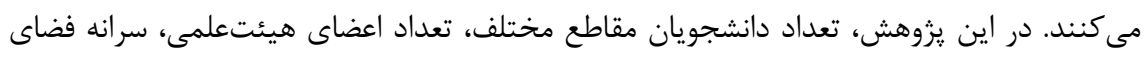

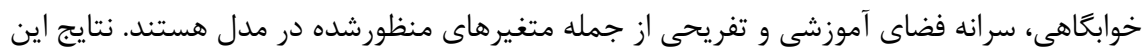

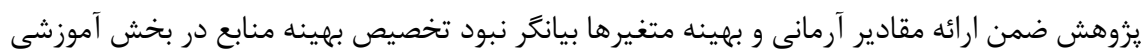

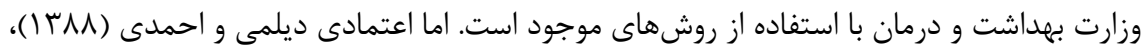
با تمركز بر نحوه توزيع منابع انسانى در مراكز بهداشتى و درمانى شهر رشت، ضمن بررسى مشكلات

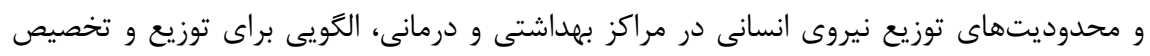

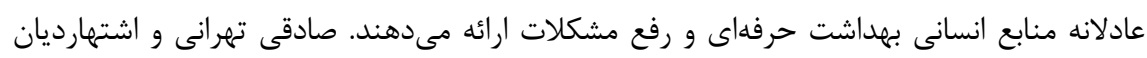

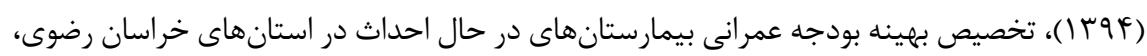

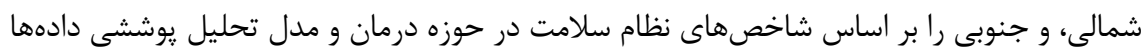


مورد بررسى قرار مىدهند. نتايج اين يزوهش كه به بر اساس محاسبه كارايى نسبى حاصل مئشود،

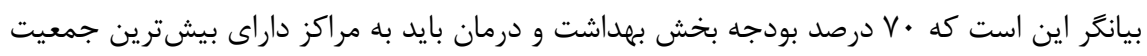

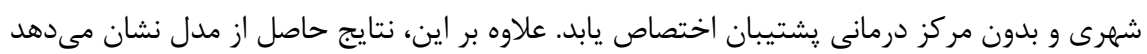

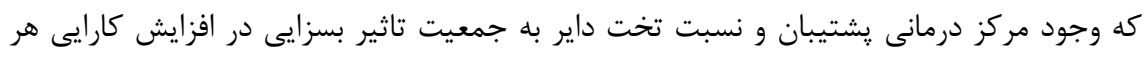

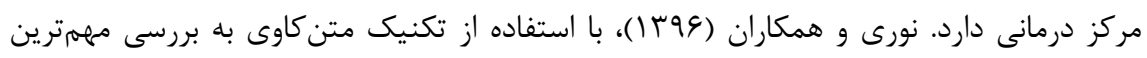

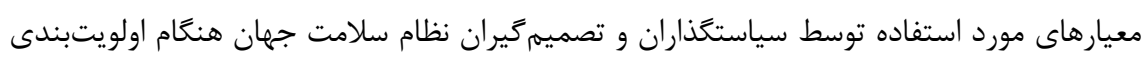

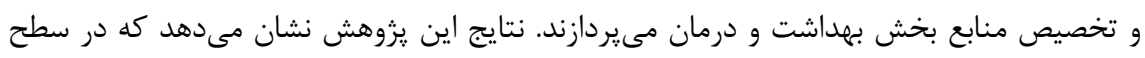

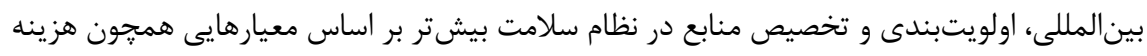

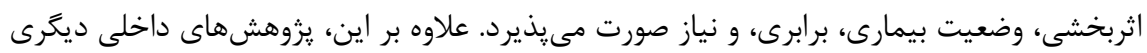

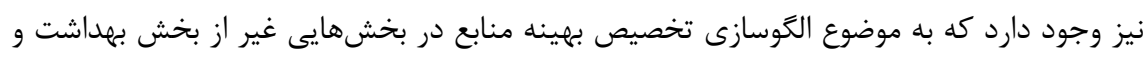

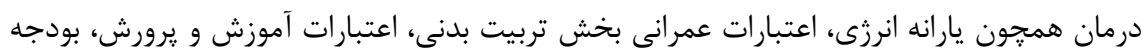

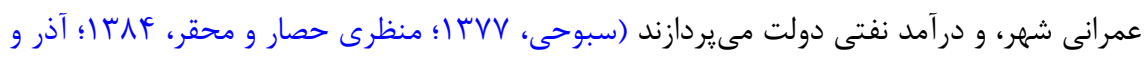

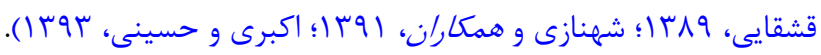

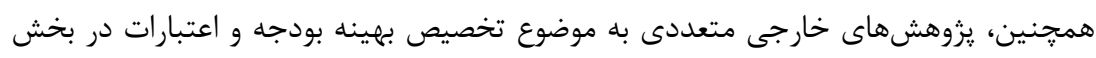

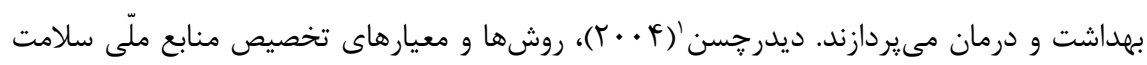

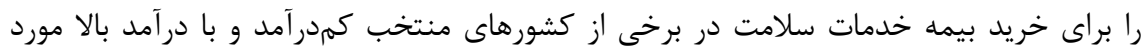

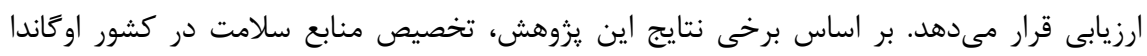

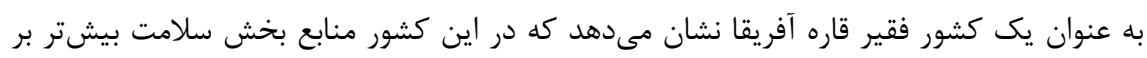

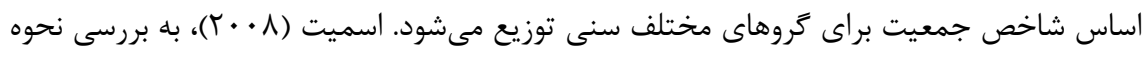

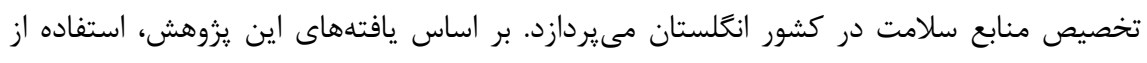

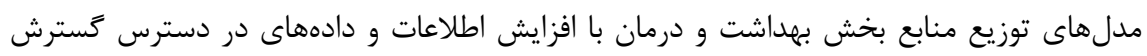

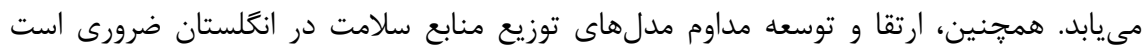

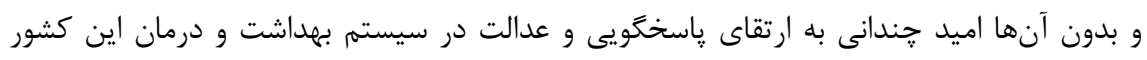

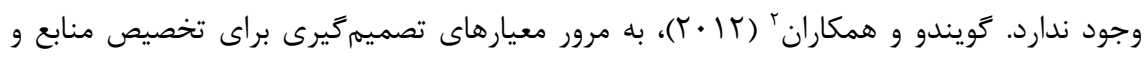

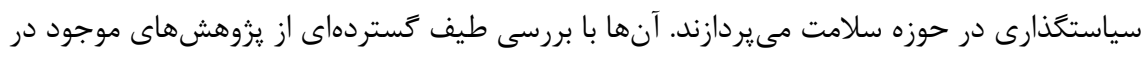


حوزه اشارهشده، معيارهاى مختلفى را در توزيع منابع بخش سلامت شناسايى و طبقهبندى مى كنند. يافتههاى آنها نشان مىدهند كه بيشترين معيارها مربوط به عدالت و برابرى در تخصيص منابع است. نتايج يائولدن و كلكستون' (Y/ (Y)، نشان مىدهد كه تخصيص بودجه بر نرخ ترجيح زمانى اجتماعى و همجنين اثربخشى هزينهها در حوزه سلامت موثر است و از طريق كاهش هزينهها به

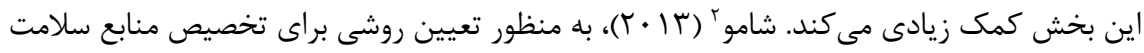

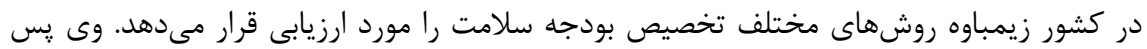

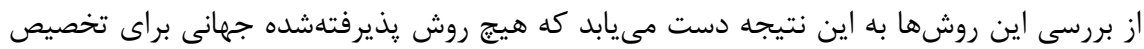

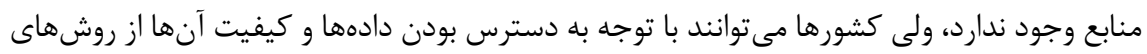

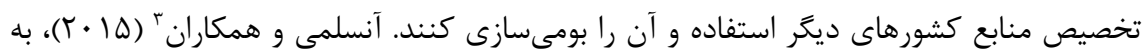
بررسى يروهشها و مدلهاى موجود در زمينه عدالت توزيع منابع مالى و مخارج بخش بهداشت و و وديع

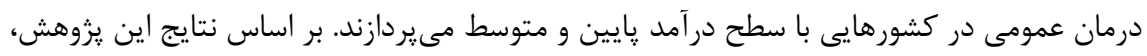
يروهشكران اين حوزه بيشتر از دو نوع روش تحليل منافع و تحليل تخصيص منابع استفاده مى كنند.

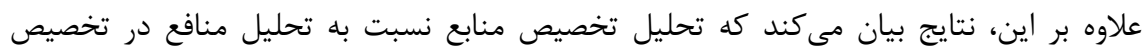

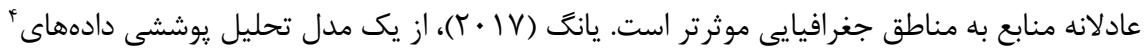

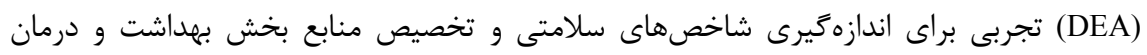

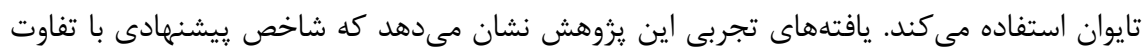
تقاضاى جمعيت براى منابع بهداشتى تطبيق بهترى دارد و مىتواند اطلاعات عملكردى معتبرترى

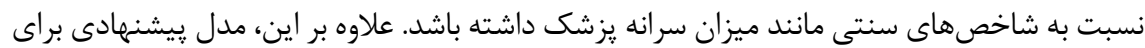

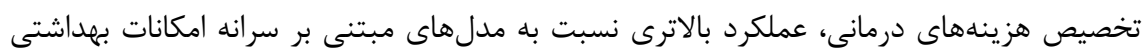

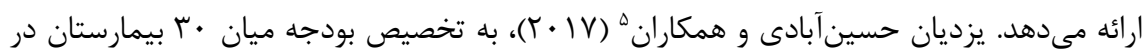

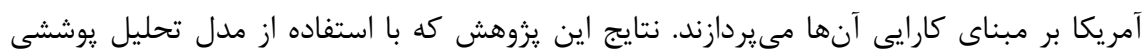
دادهها و در نظركرفتن تعداد تخت بيمارستان، خدمات تركيبى، تجهيزات تماموقت بيمارستان، و و هزينههاى عملياتى به عنوان ورودى مدل و تعداد يذيرش بيماران و ويزيتهاى سريايى به عنوان

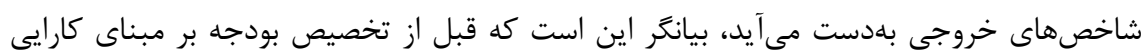

1. Paulden \& Claxton

2. Shamu

3. Anselmi et al.

4. Data Envelopment Analysis

5. Yazdian Hossein Abadi et al. 
تنها جهار بيمارستان كارايى نسبى دارند، در حالى كه بعد از تخصيص بودجه بر مبناى سناريوهاى

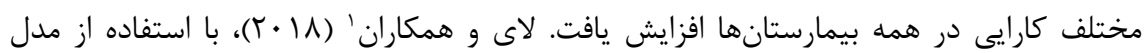
تحليل يوششى دادههاى گروهى الكويى براى تخصيص منابع بهداشت و درمان عمومى در جين ارائه مى كنند. در مدل آنها يك بيمارستان عمومى به شكل انفرادى با اين شرط مى تواند يرداختىهايش

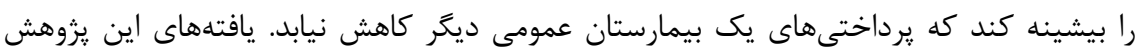

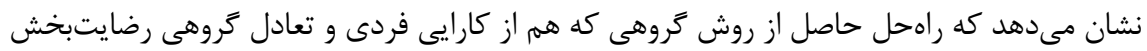
برخوردار است و هم به عنوان يك الكوريتم همخراى قابلمحاسبه مطرح است، مىتواند توسط نهاد

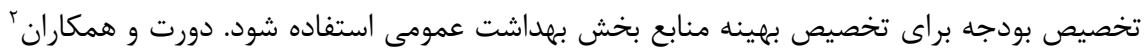

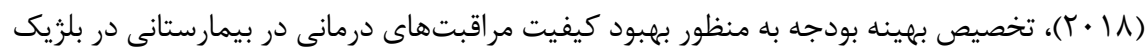
را با استفاده از تابع كاب داتلاس و برنامهريزى خطى جندهدفه مورد ارزيابى قرار مىدهند. نتايج اين يزوهش نشان مىدهد كه تخصيص بهينه بودجه براى واكسيناسيون كودكان و تخت بيمارستانى

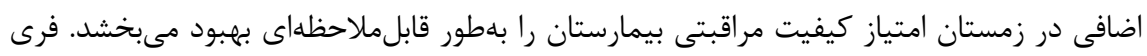

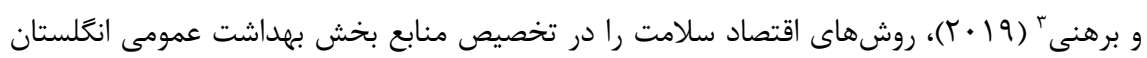
مورد ارزيابى قرار مىدهند. يافتههاى اين يزوهش نشان مىدهد كه بر اساس مشاهدهها و مصاحبهها با تصميم گيران حوزه مورد بررسى مواردى همجون تمركز محدود در بخش بهداشت و بـىتوجهى به به

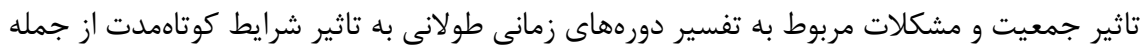

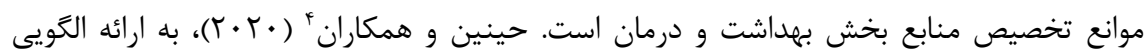
براى تخصيص منابع بخش بهداشت و درمان در فنلاند بر مبناى دو هدف بيشينهسازى منفعت كل و

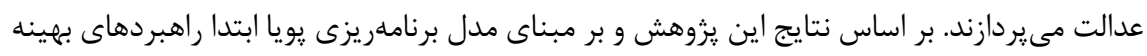
در بخش درمان و مزاياى بهداشتى مورد انتظار براى هر بخش بيمارى در سطوح مختلف هزينه تعيين

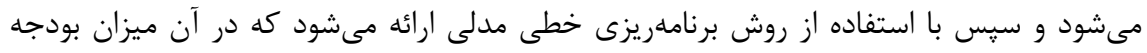
تخصيصى به هر بخش براى بيشينه شدن اهداف و سياستخذارى و محدوديت منابع مشخص ميى مشود.

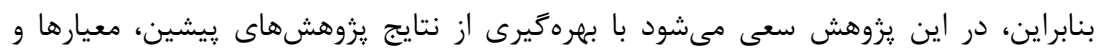

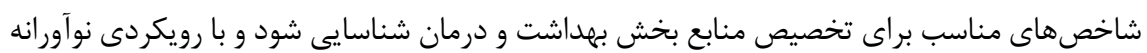

1. Lai et al.

2. Dort et al. 
مدلى دقيق و به دور از پيجٍيدگى براى تعيين مقادير واقعى اعتبارات تملك دارايىهاى سرمايهاى بخش بهداشت و درمان طراحى شود كه مىتواند به هر يك از شهرستانهاى استان خراسان رضوى

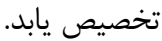

\section{روششناسى بزوهش}

اين يزوهش كاربردى با هدف طراحى الكويى براى تخصيص اعتبارات تملك دارايى هاى سرمايهاى استان خراسان رضوى براى ^^ شهرستان آن شامل باخرز، بجستان، بردسكن، بينالود، تايباد، تربت

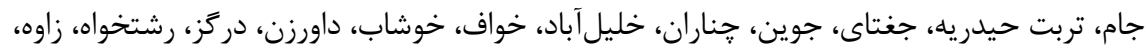
سبزوار، سرخس، فريمان، فيروزه، قوجان، كاشمر، كلات، گناباد، مشهد، مدولايت، و نيشابور بر مبناى

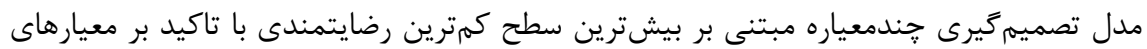

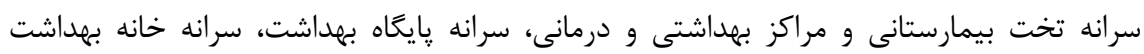

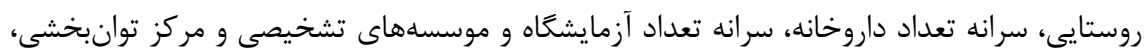

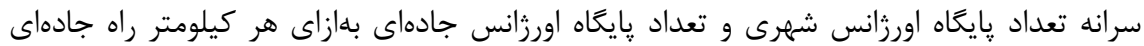
كه به روش اسنادى و كتابخانهاى از سالنامه آمارى استان خراسان رضوى' در سال و9 با استخراج

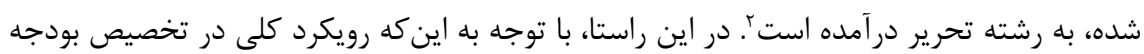

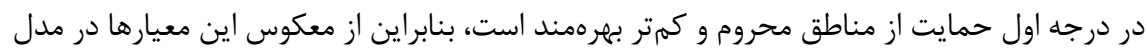

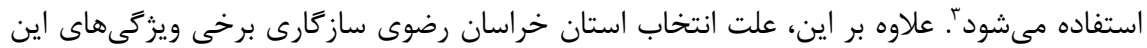

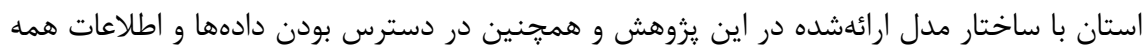

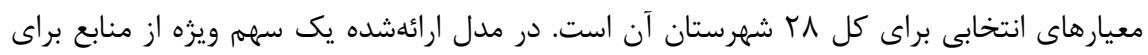

1. https://khrazavi.mporg.ir/Portal/View/Page.aspx?PageId=6281233c-30bf-45df-8d6bc8 $8227 \mathrm{c} 77628 \& \mathrm{t}=29$

ז. به دليل اينكه براى برخى شهرستانهاى استان خراسان رضوى، آمار برخى امكانات (براى مثال مركز

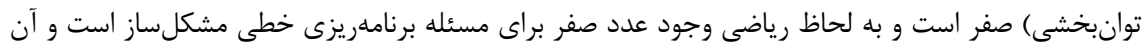
را فاقد جواب مىنمايد، بنابراين برخى از معيارها با يكديخر تركيب شدهاند.

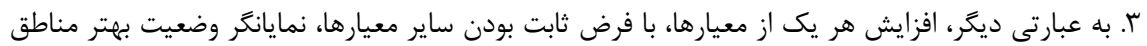

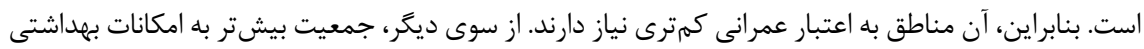

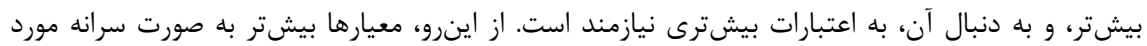


واحدى در نظركرفته مىشود كه ارائهدهنده خدمات به ساير واحدهاست و شهرستان مشهد به عنوان

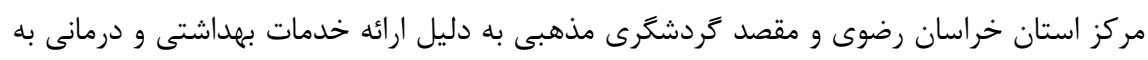

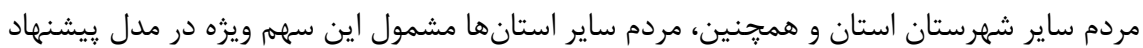
مىشود. نياز به يادآورى است كه علت انتخاب دادههاى سال وجّا اين است كه آخرين سالنامه آمارى در دسترس براى استان خراسان رضوى مربوط به همين سال است. همجنين بر اساس تعريف

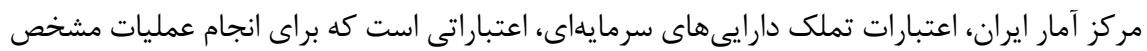
و با حفظ و توسعه دارايىهاى سرمايهاى موجود يا ايجاد دارايىهاى سرمايهاى جديد از سوى سازمان مديريت و برنامهريزى كشور در يك سال مالى به استانها ابلاغ مى

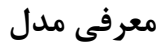

يكى از تكنيكهاى تصميمَيرى با استفاده از دادهاى كمّى، روش تصميمگيرى جندمعياره'

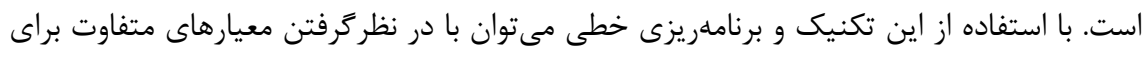

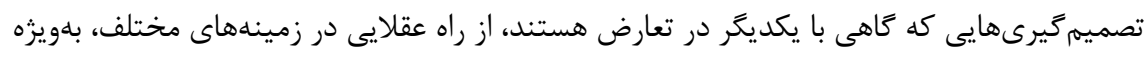
تخصيص منابع و بودجه، تصميمگيرى كرد (حسنى مقدم، بوץ (). در اين راستا، به منظور تخصيص

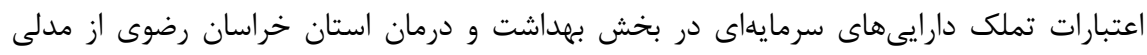

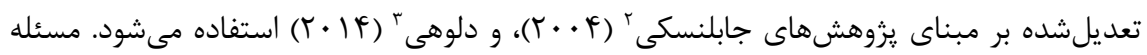
ييشارو در اين مدل، تخصيص بودجه (اعتبارات تملك دارايىهاى سرمايهاى بخش بهداشت و درمان

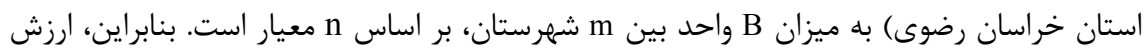

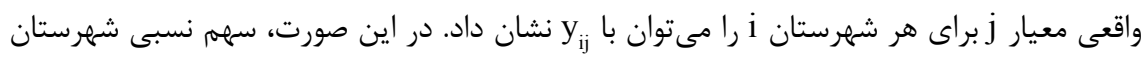

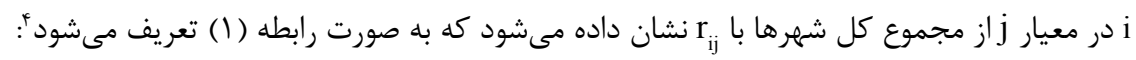

$\mathbf{r}_{\mathbf{i j}}=\frac{\mathbf{y}_{\mathbf{i j}}}{\sum_{\mathbf{i}=\mathbf{1}}^{\mathbf{m}} \mathbf{y}_{\mathbf{i j}}} \quad \mathrm{i}=1,2, \ldots, \mathrm{m} \quad \mathrm{j}=1,2, \ldots, \mathrm{n}$

1. Multi Criteria Decision Making (MCDM)

2. Jablonský

3. Dlouhý

؟. در واقع با توجه به مقياس (واحد اندازهيرى) مختلف معيارهاى انتخابى، با استفاده از اين رابطه، اين معيارها 
اكنون با توجه به كل بودجه (اعتبارات) تخصيصى به شهرستانها، ميزان (يا سهم) هر شهرستان i

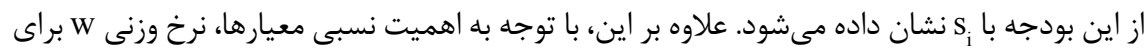

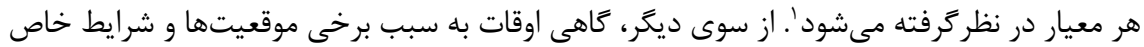
بايد براى برخى شهرستانها سهمى ويزه از كل بودجه (اعتبارات) تخصيصى در نظرگرفته شود كه در اينجا با x نشان داده مىشود. براى مثال، شهر مشهد به عنوان مركز استان به سبب در اختيار داش داشتن

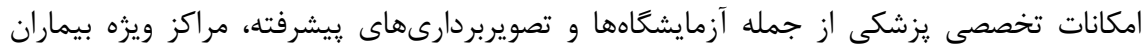
سرطانى، امكانات و تجهيزات يِيشرفته جراحى قلب، مغز و اعصاب مورد توجه مردم ساير شهرستانها

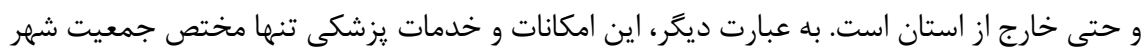

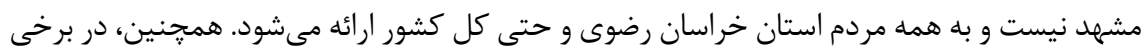
موارد در برخى شهرستانها، يروزههاى عمرانى نيمهتمامى در بخش بهداشت و درمان وجود دارد كه

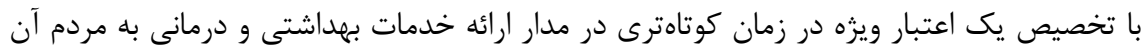

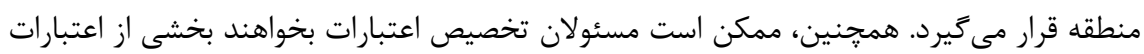
را به همان روشهاى سنتى و معيارهاى كذشته و بخشى را بر اساس مدل بيشنههادى توزيع نمايند. بنابراين، در همه اين موارد در نظركرفتن سهم ويزه مدل را به واقعيت نزديكتر مىنمايدَّ. بنابراين،

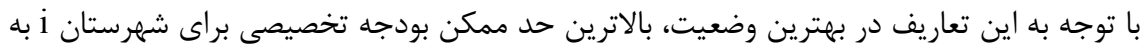

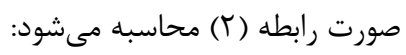

ا. با توجه به اين كه معيارهاى انتخابى اهميت نسبى متفاوتى دارند، بنابراين بايد براى آنها وزن در نظركرفته

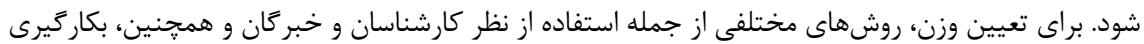

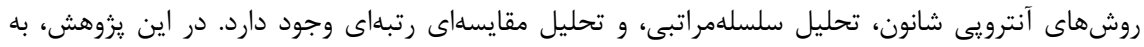

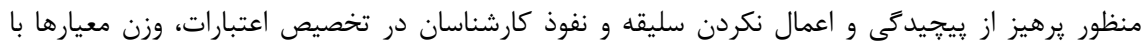

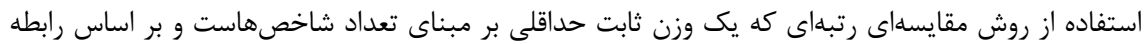

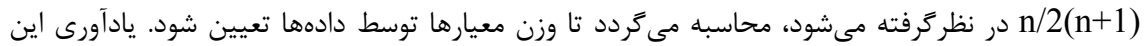

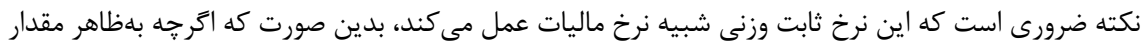

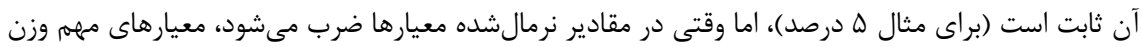
بيشترى مى ז. لحاظ كردن קند اعتبار ويزه در مدل به صورت x1,x2,,..,Xn امكانيذير است. به بيانى ديخر، ابتدا اعتبارات

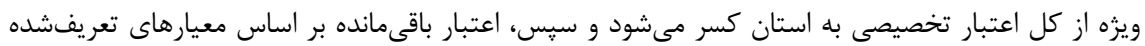
ميان شهرستان ها توزيع مىشود. 
$u_{i}=\left((1-w n) M a x_{j} r_{i j}+w \sum_{j=1}^{m} r_{i j}\right)(1-x) B$

همجنين، در نقطه مقابل و در بدترين وضعيت، يايينترين حد ممكن بودجه تخصيصى براى

$l_{i}=\left((1-w n) \operatorname{Min}_{j} r_{i j}+w \sum_{j=1}^{m} r_{i j}\right)(1-x) B$

با توجه به روابط (r) و (r)، يك شرط منطقى براى تخصيص منابع اين است كه بايد سطح

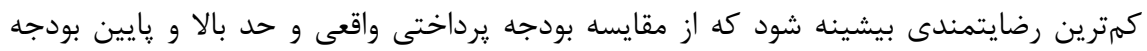
بهدست مى آيد. اين شرط را مىتوان به صورت رابطه (f) تعريف كرد:

$\frac{s_{i}-l_{i}}{u_{i}-l_{i}} \geq a_{i} \quad, \quad i=1,2, \ldots, m$

در رابطه (f)، a معرف بيشترين سطح حداقل رضايتمندى است كه بين صفر و يك تعريف

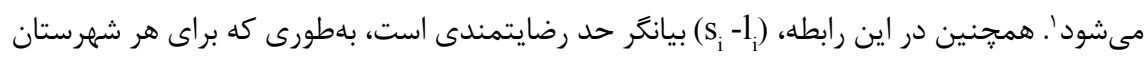

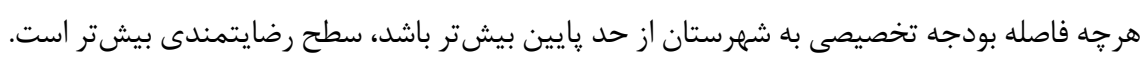

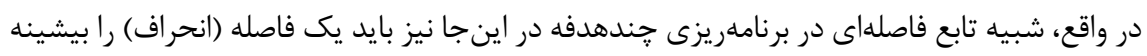

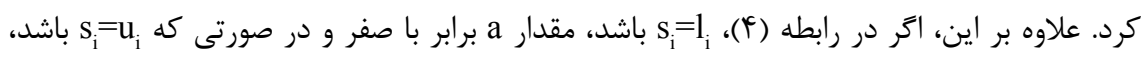

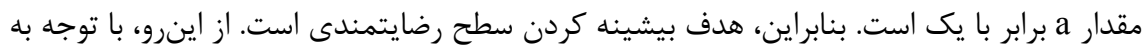
روابط ارائهشده مسئله برنامهريزى به صورت رابطه (ه) تعريف مىشود:

Max a

Subject to:

$\begin{array}{ll}\sum_{\mathrm{i}=1}^{\mathrm{s}_{\mathrm{i}}-\mathrm{l}_{\mathrm{i}}-\mathrm{a}\left(\mathrm{u}_{\mathrm{i}}-\mathrm{l}_{\mathrm{i}}\right) \geq 0} & \mathrm{i}=1,2, \ldots, \mathrm{m} \\ \mathrm{s}_{\mathrm{i}} \geq 0 & \mathrm{i}=1,2, \ldots, \mathrm{m}\end{array}$

$\mathrm{a} \geq 0$

با حل مسئله (ه)، مقادير بهينه بودجه (اعتبارات) تخصيصى به هر شهرستان بهدست مىآيد.

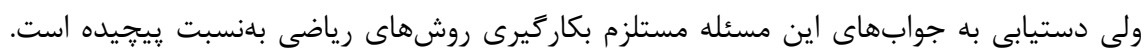

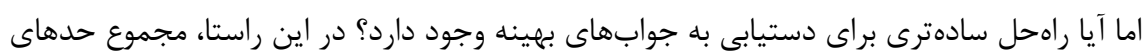

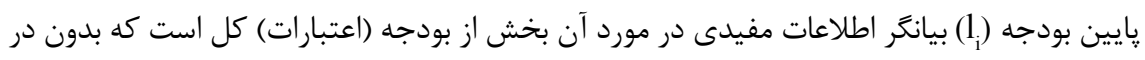
ا. محاسبه اين شاخص شبيه روشهاى نرمال كردن مشاهدهاست كه بر مبناى آن داده با استفاده از مقادير Min و Max 
نظرگرفتن ارزش واقعى وزنها به شهرستانها يرداخت مىشود. از سوى ديگر، مجموع حدهاى بالاى

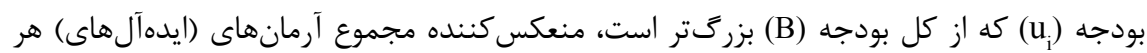
شهر است. به عبارت ديخر، اين شاخص بيانكر اين است كه براى يوشش همه انتظارهاى شهرستانها جقدر بايد به بودجه كل اضافه كرد. اكنون با مقايسه فاصله بين بودجه موجود B و مجموع حد يايين با فاصله بين مجموع حد بالا و مجموع حد يايين بودجه يرداختى به شهرستانها مقدار a بهطور $\mathrm{a}=\frac{(1-x) \mathrm{B}-\sum \mathrm{l}_{\mathrm{i}}}{\sum \mathrm{u}_{\mathrm{i}}-\sum \mathrm{l}_{\mathrm{i}}}$ مستقيم از رابطه (ع) بلهدست مى آيد:

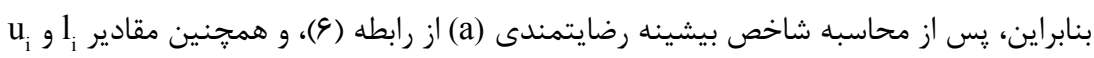

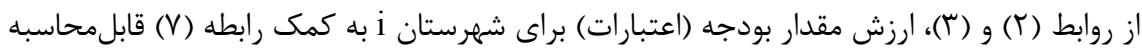

$\mathrm{s}_{\mathrm{i}}=\mathrm{l}_{\mathrm{i}}+\mathrm{a}\left(\mathrm{u}_{\mathrm{i}}-\mathrm{l}_{\mathrm{i}}\right), \mathrm{i}=1,2, \ldots, \mathrm{m}$ در اين راستا، به منظور سهولت و افزايش دقت در استفاده از اين مدل، از نرمافزار ROA براى تعيين سهم بهينه هر يك از شهرستانهاى استان خراسان رضوى بر اساس معيارهاى مربوطه بهره

\section{يافته هاى ثيزوهش}

با توجه به آن جه در بخش پيشين مورد ملاحظه قرار گرفت، اعتبارات تملك دارايىهاى سرمايهاى

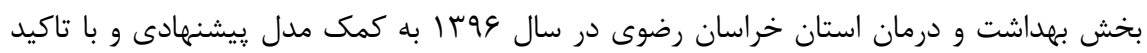

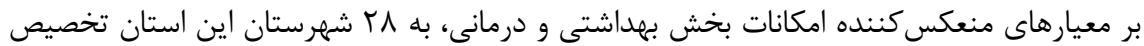
يافته است. در ابتدا، يِيش از يرداختن به نتايج مدل ييشنهادى، وضعيت تعداد تخت بيمارستانى و

ا. نياز به يادآورى است، در صورتى كه تخصيص بودجه در سطح كلان (براى مثال يك وزارتخانه) مطرح

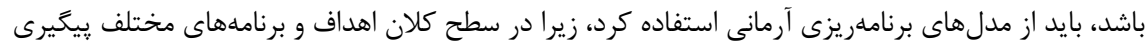

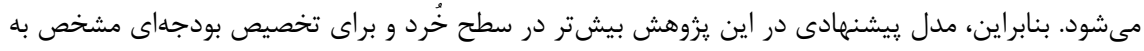
يك بخش خاص مناسب است و در سطح كلان قابل استفاده نيست.

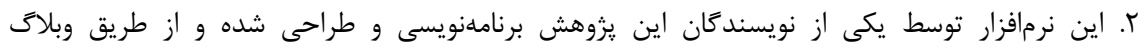

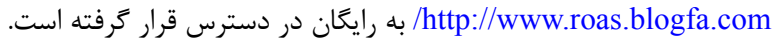


مراكز بهداشتى و درمانى، تعداد يايحاه بهداشت، تعداد خانه بهداشت روستايى، تعداد داروخانه، تعداد

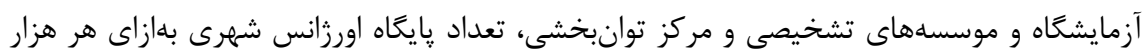
نفر جمعيت، و تعداد يايگاه اورزانس جادهاى بهازاى هر هزار كيلومتر راه جادهاى در سطح استان خراسان رضوى و كشور در سال عوبا در قالب شكل (1) به تصوير كشيده مىشود.

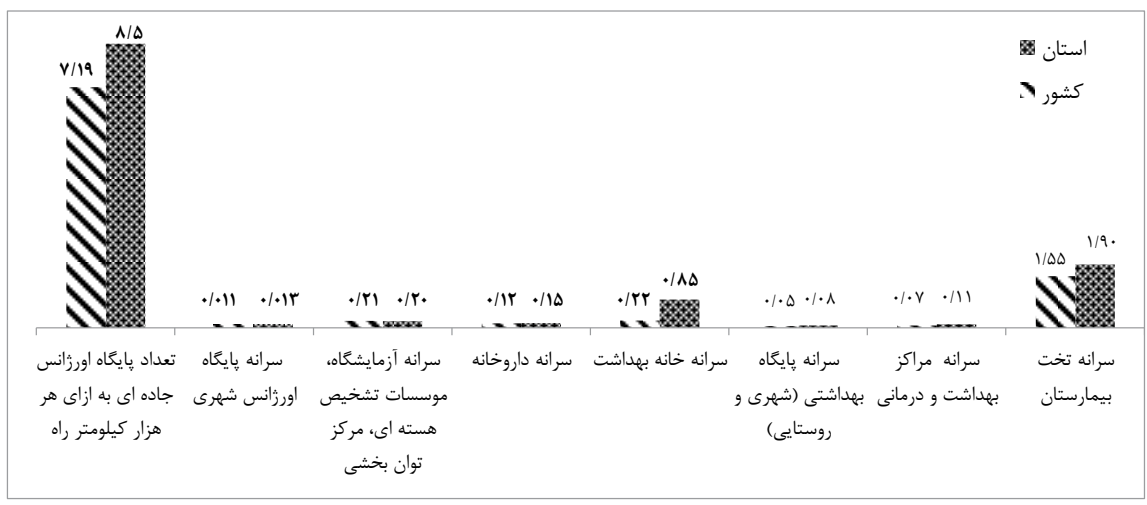

شكل 1: مقايسه وضعيت سر انه امكانات بهداشتى و درمانى در سطح استان خراسان رضوى با كل كشور در

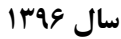

بر اساس نتايج ارائهشده در شكل (1)، بهازاى هر هزار نفر جمعيت استان خراسان رضوى 1/9

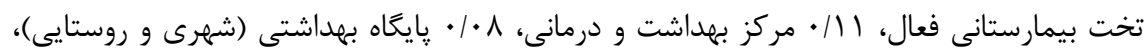

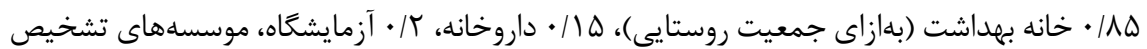

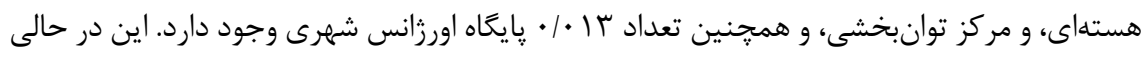

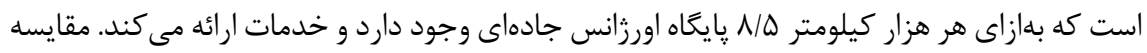
سرانه اين شاخصها در استان خراسان رضوى با سرانه آنها در كل كشور بيانكر اين واقعيت است كه آر جه استان خراسان رضوى در همه شاخصها از وضعيت بهترى نسبت به سرانه كشورى برخوردار

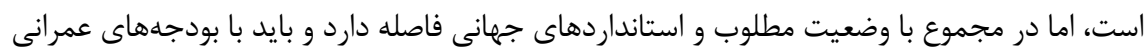
و تخصيص بهينه آنها اين امكانات و زيرساختها را به شكلى عادلانه و متوازن بهببود بخشد و تقويت

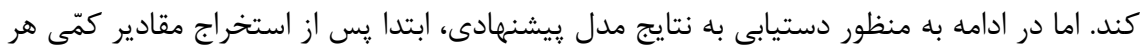

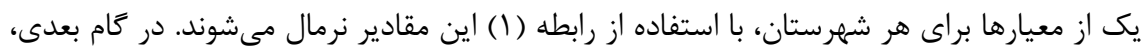




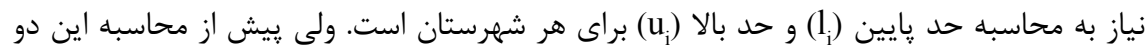

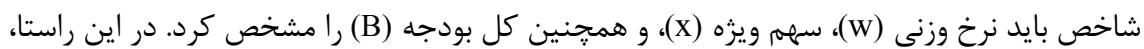

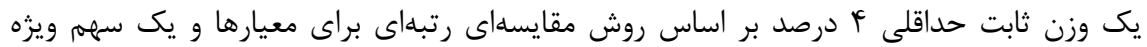

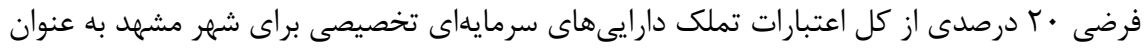

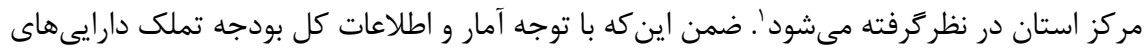

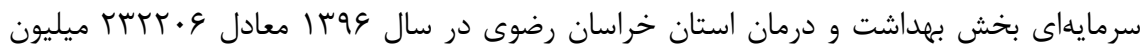

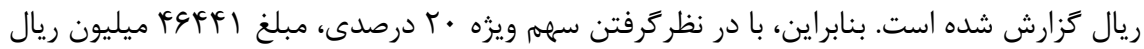

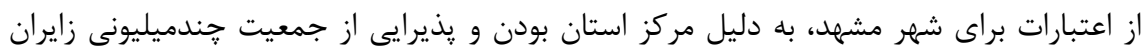

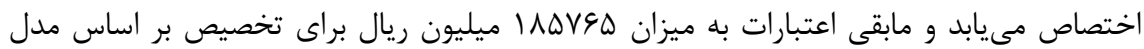

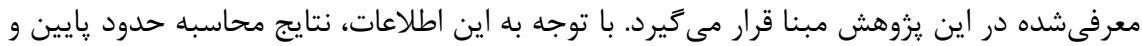

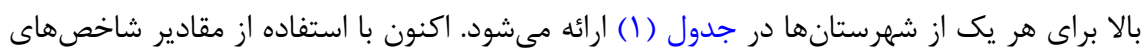

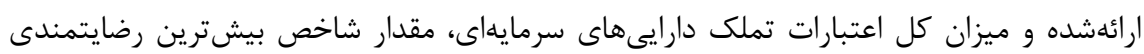

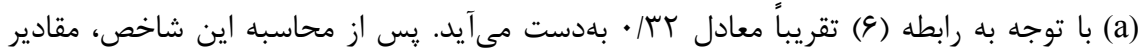

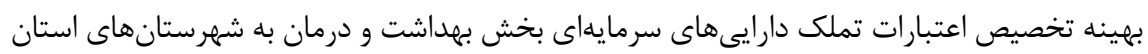
خراسان رضوى به كمك رابطه (V) محاسبه مىشود.

جدول ا: سهم و ميزان اعتبارات تملك دارايعهاى سرمايهاى بهينه در بخش بهداشت و درمان شهر ستانهاى استان خراسان رضوى در سال وهجا1 (ارقام به ميليون ريال)

\begin{tabular}{|c|c|c|c|c|}
\hline 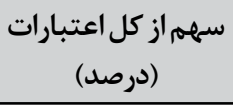 & ميزينهاناعتبارات & حد بالا (U) & حد پيايين (I) & شهرستان \\
\hline G/Ar & $\mid Q \wedge \Delta F$ & FIV.r & MGAT & مشهد \\
\hline ४/^9 & ||$r q \mid$ & TEIFF & frov & بينالود \\
\hline$F / \Delta r$ & $1 \cdot \Delta \cdot \Lambda$ & rID99 & DTAT & زاوه \\
\hline$f / f)$ & I.rTV & TITAF & 0.11 & تربتجام \\
\hline$r / r q$ & $11 \cdot 1$ & $19 \vee 90$ & एव१द & خوشاب \\
\hline
\end{tabular}

ا. با توجه به روابط مدل ميزان سهم ويزه (X)، به دليل اين كه ابتدا از كل بودجه (B) كسر مىشود، تاثيرى در نتايج و سهمهاى بهينه ندارد. بنابراين، در اينجا براى ارائه سهمهاى بهينه يك سهم ويزه • · درصد براى شهر مشهد به دلايل اشارهشده فرض مىشود كه در نتايج خروجى از مدل (سهم بهينه هر شهرستان) تاثيرى ندارد. 
ادامه جدول ا: سهم و ميزان اعتبارات تملك دارايیهاى سرمايهاى بهينه در بخش بهداشت واش و دورمان

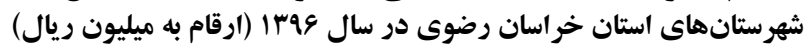

\begin{tabular}{|c|c|c|c|c|}
\hline 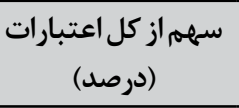 & ميزاناعتبارات & حد بالا (U) & حد يايين (1) & شهرستان \\
\hline$r / F F$ & V११V & ITYFD & 0919 & جناران \\
\hline$r / T V$ & Vबq. & $199 \cdot Y$ & וזسץ & فيروزه \\
\hline$r / \cdot q$ & VIV. & 11901 & $q q \cdot 1$ & خليل آباد \\
\hline$r / \cdot V$ & VIrA & $|F| V D$ & rیוr & جغتاى \\
\hline$r / \cdot V$ & virv & IrTFa & FFFq & قو جان \\
\hline r/99 & GqFT & ITAKV & $f \mid Q \Lambda$ & باخرز \\
\hline К/А & SVIV & IrqIV & טוTH & داورزن \\
\hline T/Ar & $9 \Delta \vee q$ & $I T V D D$ & rघq. & كاشمر \\
\hline$r / \Lambda \cdot$ & 9490 & 1.918 & $F \varphi \cdot \Delta$ & خواف \\
\hline T/FQ & $\Delta V \cdot G$ & Irraf & TAFA & سبزوار \\
\hline T/Tq & 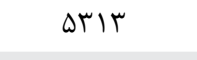 & $\vee q \cdot v$ & $\mathcal{r} \cdot \wedge V$ & مدولات \\
\hline$r / T \Lambda$ & $\Delta r \cdot r$ & VAvq & $\hat{f} \cdot \wedge f$ & سرخس \\
\hline$T / T \Lambda$ & Drq. & $\Lambda \Lambda Y^{\prime}$ & roqv & تايباد \\
\hline$T / T V$ & $\Delta r \wedge I$ & VDIT & Frty & ر رشتخواه \\
\hline T/IF & Fqvi & $\Lambda \cdot 9 \gamma$ & $r \Delta \cdot \Lambda$ & جوين \\
\hline r/T & pqrq & \&स१Q & FYOI & بردسكن \\
\hline$r / 11$ & $p q \cdot 1$ & $1 \cdot 11$ & reft & فريمان \\
\hline$r / \cdot 1$ & rध49 & $\Lambda \Delta \cdot V$ & r^DS & كلات \\
\hline 1/94 & 4F^q & VTII & $r T^{\prime} \cdot r$ & نيشابور \\
\hline $1 / V$ & гqтq & $V T \wedge \Lambda$ & rrav & بجستان \\
\hline $1 / 99$ & TQY) & $\Delta 910$ & rqvq & درز \\
\hline $1 / 9$. & rvis & $q \cdot \wedge V$ & rब१९ & تربت حيدريه \\
\hline $1 / 01$ & TYqD & 9990 & INFT & كَاباد \\
\hline$\wedge \cdot$ & INQVVT & $r \Delta \Delta / 9 T$ & $1 \cdot \Delta V \backslash \varepsilon$ & مجموع \\
\hline
\end{tabular}


و درمان استان خراسان رضوى به شهرستانهاى اين استان در قالب مدل ارائهشده در اين يزووهش

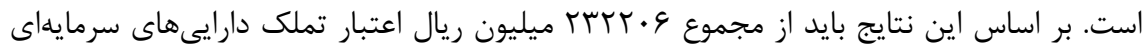

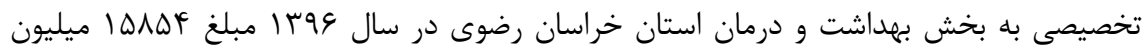

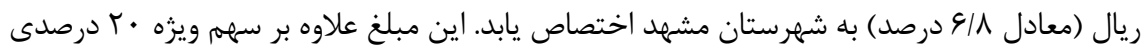

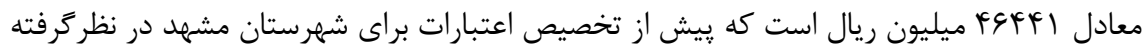

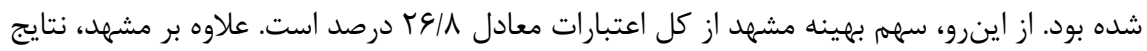

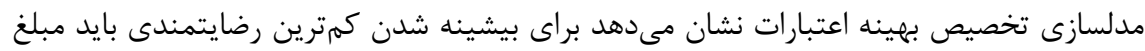

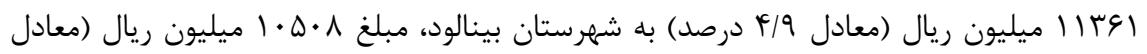

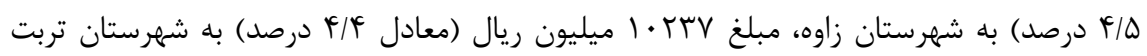

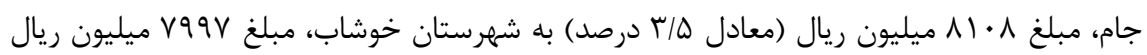

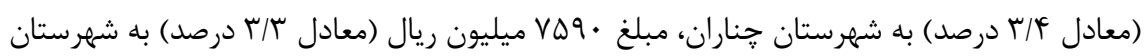

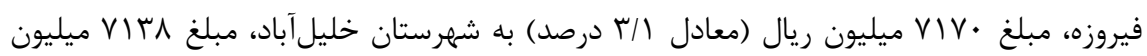

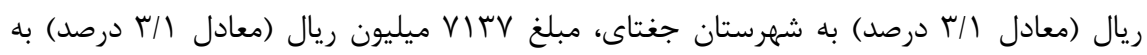

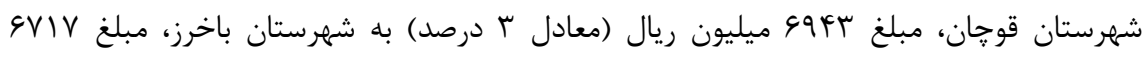

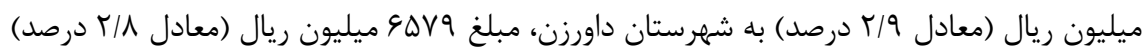

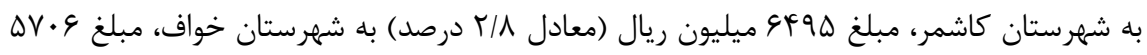

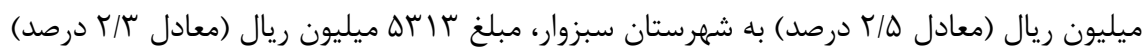

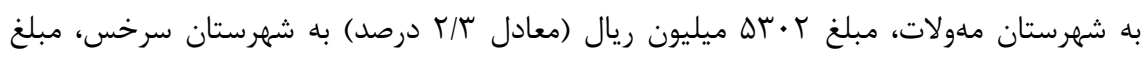

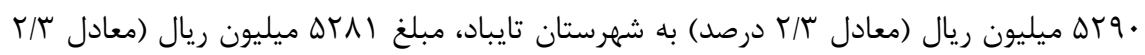

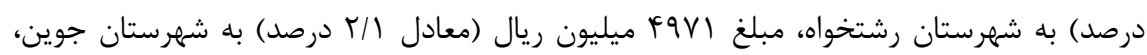

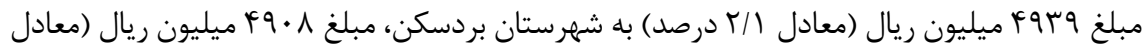

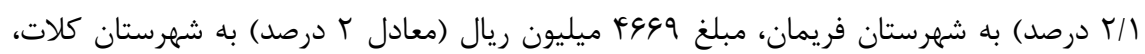
مبلغ 1/Y

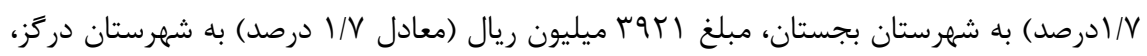

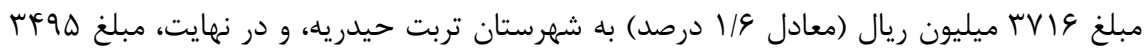

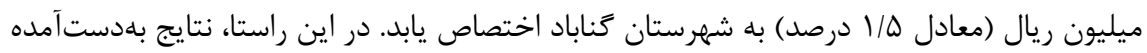

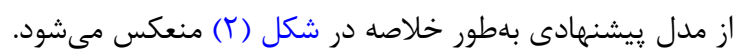




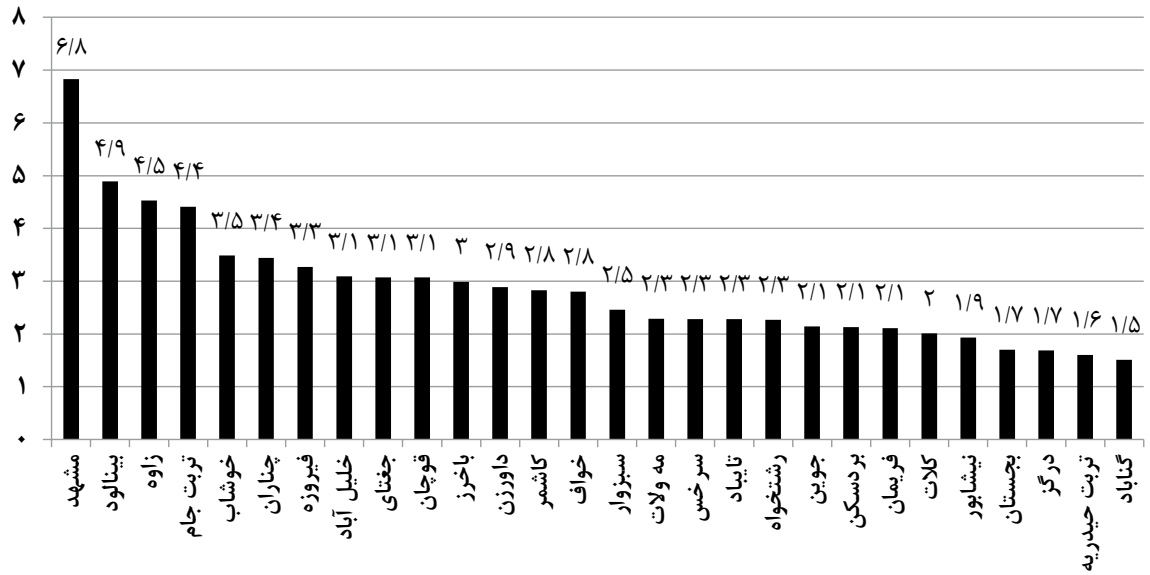

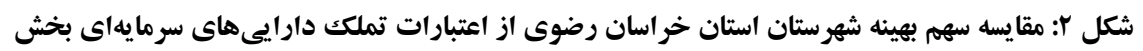

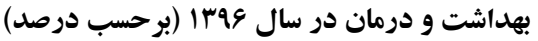

نتايج شكل (ז)، بيانكر اين است كه شهرستان مشهد داراى بالاترين سهم بهينه (بدون در

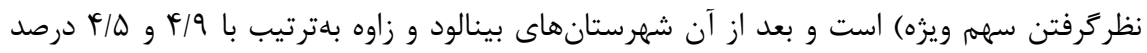

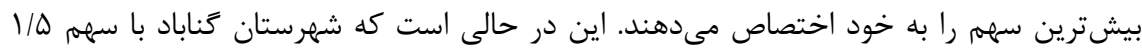
درصدى داراى كمترين سهم بهينه از اعتبارات تملك دارايىهاى سرمايهاى بخش بهداشت و درمان

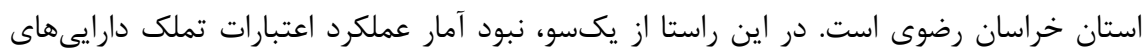
سرمايهاى بخش بهداشت و درمان استان خراسان رضوى به تفكيك شهرستانها، امكان مقايسه اين ارقام را با ميزان اعتبارات بهينه شهرستانها، كه بر مبناى مدل يِيشنهادى در اين يزوهش

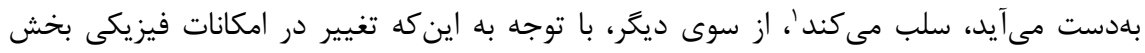

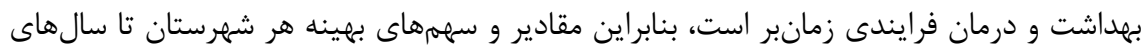
بعد قابلاستفاده هستند. بنابراين، اعتبارات هر سال مىتواند به كمك مدل ريشنههادى و با توجه به به

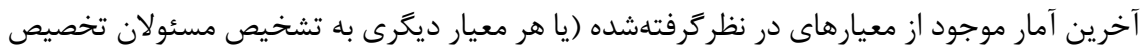
ا. در بخش آمار و اطلاعات سازمان برنامه بودجه استان خراسان رضوى عملكرد اعتبارات تملك دارايى

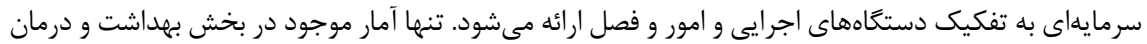

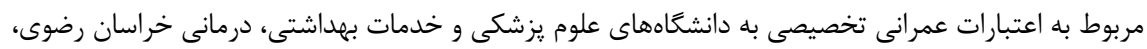

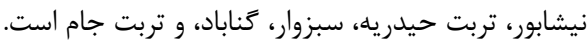


بودجه)، به شكلى منطقى و عادلانه بين شهرستانهاى استان خراسان رضوى توزيع شود.

\section{بحث و نتيجه كيرى}

هدف اين يزوهش، تخصيص منطقهاى اعتبارات تملك دارايىهاى سرمايهاى بخش بهداشت و درمان استان خراسان رضوى بر اساس يك الكَى تصميمگيرى جندمعياره مبتنى بر سطح رضايتمندى است. بر اساس نتايج اين يزوهش كه بر مبناى آزمون مدل تبيين مىشود و بر اساس آمار و اطلاعات

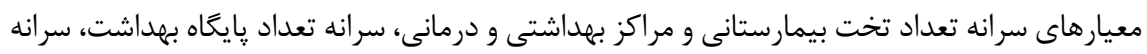

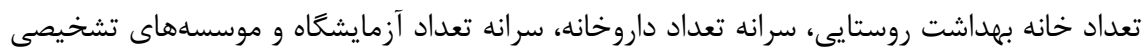

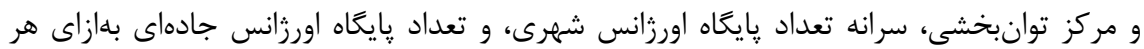

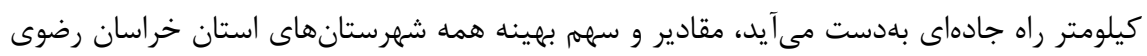

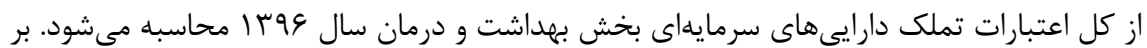
اساس اين نتايج، بالاترين سهمهاى بهينه مربوط به شهرستانهاى مشهد، بينالود، و زاوه، و پايينترين سهمم بهينه مربوط به شهرستان گَناباد است. اين در حالى است كه شاخص بيشينه رضايتمندى در

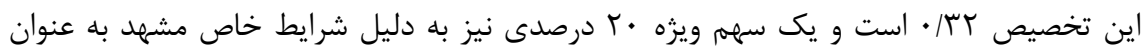
مركز استان در نظركرفته مىشود. در اين راستا، سهم اين يزوهش توجه به تخصيص منطقهاى اعتبارات تملك دارايىهاى سرمايهاى

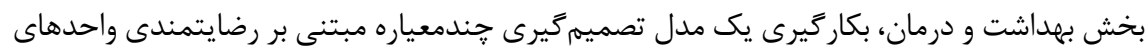

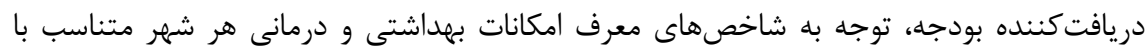
جمعيت آنها، توجه به وزن شاخصها در مدل ييشنهادى و طراحى يك نرمافزار جديد براى حل

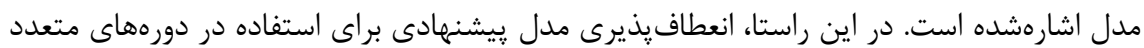

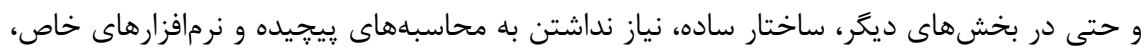

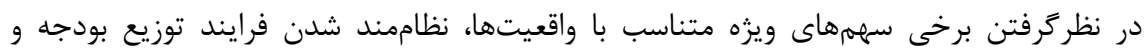
اعتبارات محدود در يك بخش خاص، توزيع عادلانه منابع بدون توجه به ملاحظات حزبى و سياسى و و فشار لابىها، افزايش سطح رضايتمندى مردم از دولت و دستگاههاى اجرايى ذىربط، بهببود وضعيت

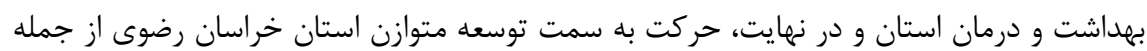

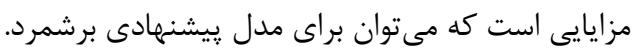


اين در حالى است كه تعيين مقادير نرخ وزنى معرف اهميت معيارها، تعيين اعتبارات ويزه براى برخى شهرستان و نبود توجه به مبحث كارايى از جمله محدوديتهاى مدل ييشنهادى است، بلنحوى كه

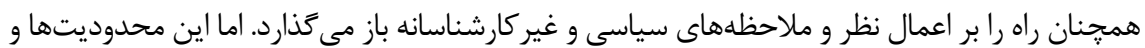

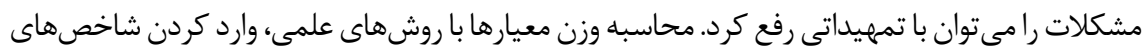

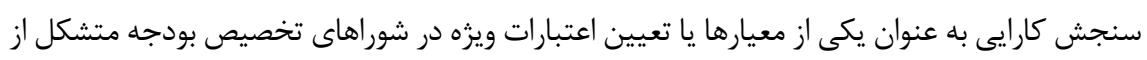

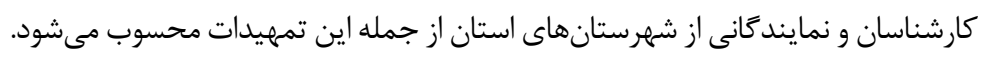

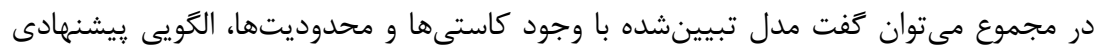
در جهت تحقق عدالت در توزيع منابع، توسعه متوازن، و افزايش سطح رضايت مردم است. بنابراين،

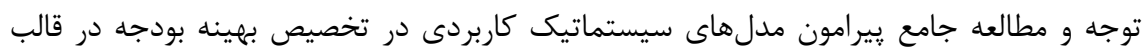

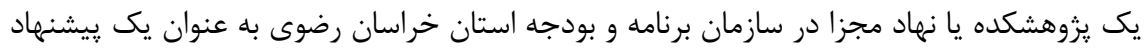
كاربردى مسير توسعه متوازن و توزيع عادلانه منابع محدود را هموارتر مى كند. علاوه بر اين، ارائه

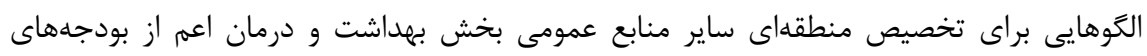

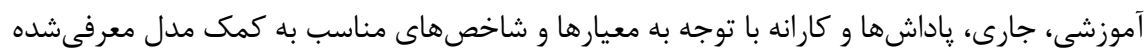

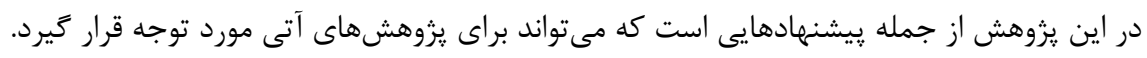

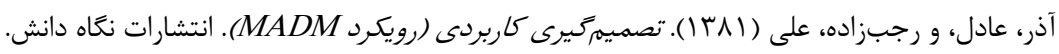

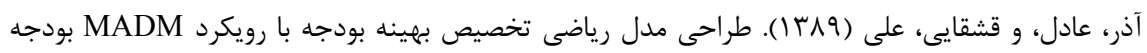

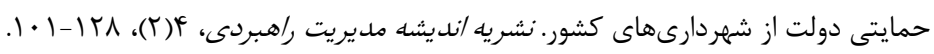

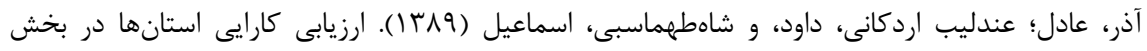

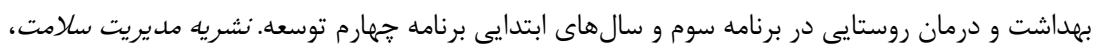

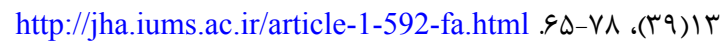

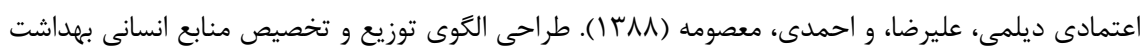

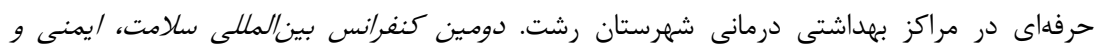


اكبرى، نعمتالله، و حسينى، سيدهمحبوبه (بوب()). بكاركيرى الكَوى برنامهريزى آرمانى در تخصيص

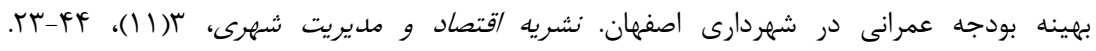
http://iueam.ir/article-1-195-fa.html

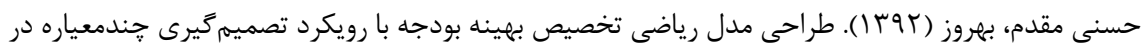

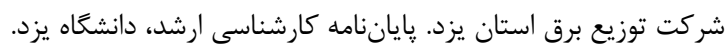

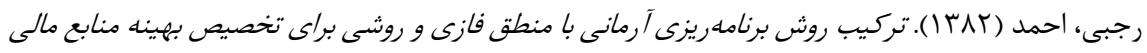

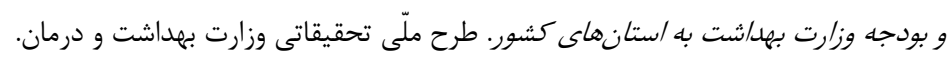

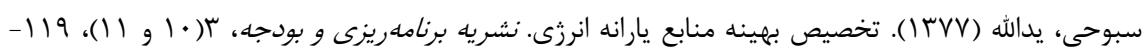

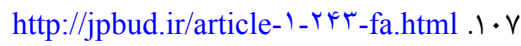
شهنازى، روحالله؛ خوشاخلاق، رحمان، و رنانى، محسن (1) (1). تخصيص بهينه دريافتىهاى نفتى دولت

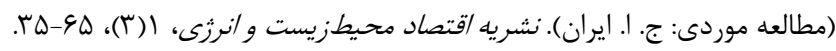

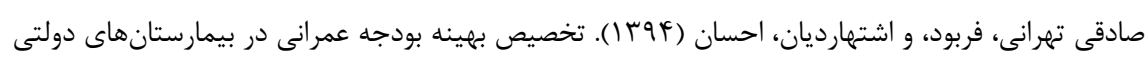

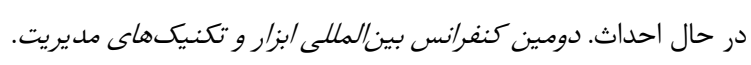

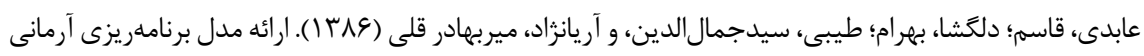

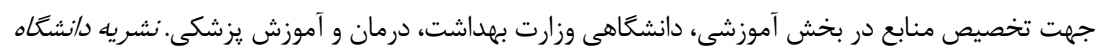

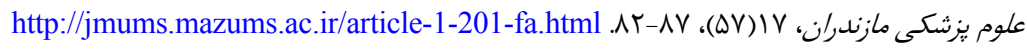

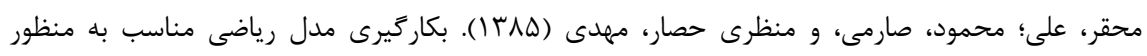

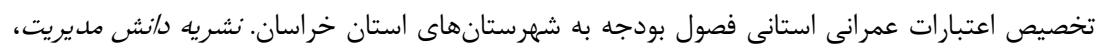
$.9 r-9 \Lambda ،(Y) 19$

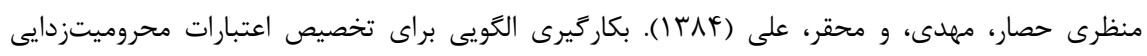

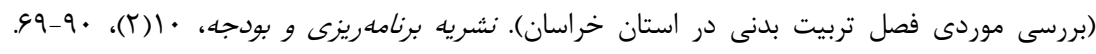
http://jpbud.ir/article-1-203-fa.html نورى، سميه؛ رياحى، ليلا؛ حاجى نبى، كامران، و جهانگيرى، كتايون (99ץ|). معيارهاى تخصيص منابع

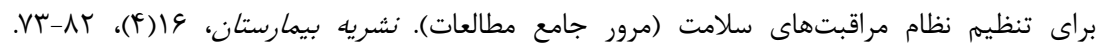
http://jhosp.tums.ac.ir/article-1-5828-fa.html

Anselmi, L., Lagarde, M., \& Hanson, K. (2015). Equity in the Allocation Public Sector Financial Resources in Low-and Middle-Income Countries: A Systematic Literature Review. Health Policy and Planning, 30(4), 528-545. https://doi.org/10.1093/heapol/czu034 
Birch, S., Eyles, J., Hurley, J., Hutchison, B., \& Chambers, S. (1993). A Needs-Based Approach to Resource Allocation in Health Care. Canadian Public Policy/Analyse de Politiques, 19(1), 68-85. https://doi.org/10.2307/3551791

Bloom, D. E., Canning, D., \& Sevilla, J. (2004). The Effect of Health on Economic Growth: A Production Function Approach. World Development, 32(1), 1-13. https://doi.org/10.1016/j.worlddev.2003.07.002

Brailsford, S., \& Vissers, J. (2011). OR in Healthcare: A European Perspective. European Journal of Operational Research, 212(2), 223-234. https://doi.org/10.1016/j.ejor.2010.10.026

Diderichsen, F. (2004). Resource Allocation for Health Equity: Issues and Methods, Resource Allocation for Health Equity: Issues and Methods. Health, Nutrition and Population (HNP) Discussion Paper, World Bank. http://hdl.handle.net/10986/13619

Dlouhý, M. (2014). Models of Subsidy Allocation among City Districts. Prague Economic Papers, 23(1), 108-120.

Dort, T., Schecroun, N., \& Standaert, B. (2018). Improving the Hospital Quality of Care during Winter Periods by Optimizing Budget Allocation between Rotavirus Vaccination and Bed Expansion. Applied Health Economics and Health Policy, 16(1), 123-132. https://doi.org/10.1007/s40258-017-0362-6

Flessa, S. (2000). Where Efficiency Saves Lives: A Linear Programme for the Optimal Allocation of Health Care Resources in Developing Countries. Health Care Management Science, 3(3), 249-267. https://doi.org/10.1023/A:1019053710258

Frew, E., \& Breheny, K. (2019). Health Economics Methods for Public Health Resource Allocation. Health Economics, Policy, and Law, 15(1), 128-140. https://doi.org/10.1017/S174413311800052X

Gugushvili, A. (2007). The Advantages and Disadvantages of Needs-Based Resource Allocation in Integrated Health Systems and Market Systems of Health Care Provider Reimbursement. Munich Personal Repec Archive, University of Edinburgh, Scotland, MPRA Paper, No. 3354.

Guindo, L. A., Wagner, M., Baltussen, R., Rindress, D., van Til, J., Kind, P., \& Goetghebeur, M. M. (2012). From Efficacy to Equity: Literature Review of Decision Criteria for Resource Allocation and Healthcare Decision Making. Cost Effectiveness and Resource Allocation, 10(9), 1-13. https://doi.org/10.1186/1478-7547-10-9

Hopkins, D. S., Larréché, J.-C., \& Massy, W. F. (1977). Constrained Optimization of a University Administrator's Preference Function. Management Science, 24(4), 365-377. https://doi.org/10.1287/mnsc.24.4.365

Hynninen, Y., Vilkkumaa, E., \& Salo, A. (2020). Operationalization of Utilitarian and Egalitarian Objectives for Optimal Allocation of Health Care Resources. Decision Sciences, 1-40. https://doi.org/10.1111/deci.12448

Jablonský, J. (2004). Modely hodnocení efektivnosti produkčních jednotek [Models for Efficiency Evaluation of Decision Making Units]. Politická ekonomie, 52(2).

Katsaliaki, K., \& Brailsford, S. C. (2007). Using Simulation to Improve the Blood Supply Chain. Journal of the Operational Research Society, 58(2), 219-227. https://doi.org/10.1057/palgrave.jors.2602195

Lai, K. K., Cheung, M. T., \& Fu, Y. (2018). Resource Allocation in Public Healthcare: A Team-DEA Model. Journal of Systems Science and Complexity, 31(2), 463-472. 
https://doi.org/10.1007/s11424-017-6124-6

Parker, B. R. (1983). A Program Selection/Resource Allocation Model for Control of Malaria and Related Parasitic Diseases. Computers \& Operations Research, 10(4), 375389. https://doi.org/10.1016/0305-0548(83)90012-6

Paulden, M., \& Claxton, K. (2012). Budget Allocation and the Revealed Social Rate of Time Preference for Health. Health Economics, 21(5), 612-618. https://doi.org/10.1002/hec.1730

Shamu, S. (2013). Literature Review on Needs Based Resource Allocation, Rebuilding the Foundations for Universal Health Coverage With Equity in Zimbabwe. Rebuild Consortium. 1-22.

Smith, P. C. (2008). Resource Allocation and Purchasing in the Health Sector: The English Experience. Bulletin of the World Health Organization, 86(1), 884-888.

Tauber, A. I. (2002). Medicine, Public Health, and the Ethics of Rationing. Perspectives in Biology and Medicine, 45(1), 16-30. 10.1353/pbm.2002.0018

Vissers, J. M. (1998). Patient Flow-Based Allocation of Inpatient Resources: A Case Study. European Journal of Operational Research, 105(2), 356-370. https://doi.org/10.1016/S0377-2217(97)00242-7

Yang, C.-C. (2017). Measuring Health Indicators and Allocating Health Resources: A DEA-Based Approach. Health Care Management Science, 20(3), 365-378. https://doi.org/10.1007/s10729-016-9358-2

Yazdian Hossein Abadi, N., Noori, S., \& Haeri, A. (2017). The Use of Resource Allocation Approach for Hospitals Based on the Initial Efficiency by Using Data Envelopment Analysis. Journal of Health Management \& Informatics, 4(4), 101-106. 